\title{
(Re)Positioning of Inter- and Intra-Lingual Translational Adventures
}

\section{Hülya BOY*}

This study analyzes Bir Çalgıcının Seyahati (The travels of a musician) within the context of its inter-/intra-lingual translations in the Turkish literary and cultural system. Initially serialized in Saadet, Bir Çalgıcının Seyahati was published in Ottoman script by Saadet Matbaas1 in 1907/1908 [1323] and by İkbal Kütüphanesi in 1921 [1337] and 1926. The first Latin script edition of this text in book form was published by Semih Lûtfi (ca. 1945). In this edition, which lacks an author's name, Mehmet Tevfik is presented as the book's translator. Although the work was analyzed and categorized as an 'interlingual translation' based on Joseph Freiherr von Eichendorff's (1826) Aus dem Leben eines Taugenichts (From the Life of a Good-for-Nothing) (Sahin 2005; Şahin 2012; Öncü 2017), it was also claimed to be an "original"/“indigenous work" (Tevfik 1945, back cover of vol. 2; Çalapala 1972, 5; Gündüz 2017, 39) and was regarded as a "pseudo translation" (Tahir Gürçağlar 2008, 228). In light of these claims, this study explores the interlingual translational adventure of the work. Another edition without an author's name was produced by Yeni Kitapçı in 1937 and contains the note, "Translator: Kemal Tahir." The same text was later published in 1945 and 1953 by Ahmet Halit Yaşaroğlu as "adjusted and transferred from German by Kemal Tahir" and is categorized as an 'interlingual translation' (Öncü 2017). Tahir's work was also referred to as a "revision" (Şahin 2005, 2; Tahir Gürçağlar 2008, 228) or "summary" (Çalapala 1972, 5) of Tevfik's text. Taking the relationship between Tahir's and Tevfik's texts as 'intralingual translation,' this study provides an analysis of the similarities and differences between the two texts within the context of translation studies.

Keywords: Bir Çalgıcının Seyahati; Aus dem Leben eines Taugenichts; translation/original; pseudo translation; intralingual translation

\section{Introduction}

Bir Çalgıcının Seyahati (The travels of a musician) was introduced to the Turkish literary and cultural system as a serial in the newspaper Saadet. ${ }^{1}$ It was printed in book form three times prior to the Turkish language reform: a two-volume edition in 1907/1908 [1323] published by Saadet Matbaası and 1921 [1337] and 1926 editions by İkbal Kütüphanesi. Although none of these editions in Ottoman script included the author's name or the title of

\footnotetext{
* Research assistant at Marmara University, Istanbul; PhDc at Yıldız Technical University, Istanbul. E-mail: hulya.boy@marmara.edu.tr; ORCID ID: https://orcid.org/0000-0002-4491-3560.

(Received 22 July 2019; accepted 17 December 2019)

${ }^{1}$ This information was provided on the cover of the work's first Ottoman script edition in book form.
} 
the original, Mehmet Tevfik was designated as the translator from German (see fig. 1 in the appendices). In 1945, ${ }^{2}$ when Semih Lûtfi published a two-volume Latin script edition of the work, it too designated Tevfik as translator on the front covers (see fig. 2). It can be suggested, however, that the differing views of Bir Çalgıcının Seyahati as produced by Tevfik reflect a larger discussion regarding the work's categorization as a 'translation' or an 'original.' Şehnaz Tahir Gürçağlar (2008), for example, described Bir Çalgıcının Seyahati as "a pseudo translation originally written by Mehmet Tevfik in Ottoman script" (228). On the other hand, there is a work which allegedly serves as the source text for Bir Çalgıcının Seyahati: a German novella by Joseph Freiherr von Eichendorff (1826) entitled Aus dem Leben eines Taugenichts (From the Life of a Good-for-Nothing). Others, though, have claimed that Bir Çalgıcının Seyahati owes nothing more than its "inspiration" to Aus dem Leben eines Taugenichts (Tevfik 1945, back cover of vol. 2; Çalapala 1972, 6; Gündüz 2017, 39), and that Bir Çalgıcının Seyahati is, therefore, not a 'translation' but an 'original.' In previous studies, however, the work was examined and categorized as an interlingual translation' based on Aus dem Leben eines Taugenichts (Şahin 2005; Şahin 2012; Öncü 2017). That being the case, this study examines the similarities and differences between the two texts from the perspective of translation studies.

In addition to the above complexities, journalist-author Rakım Çalapala (1972) also notes that, while Bir Çalgıcının Seyahati's first three Ottoman script editions in book form and its 1945 Latin script edition by Semih Lûtfi "remained faithful to its original," 3 there are other "editions published in a quite abridged form that we could call a 'summary", (5). What Çalapala refers to here as a 'summary' are editions bearing Kemal Tahir's name as the translator. The first of these is the $1937^{4}$ edition published by Yeni Kitapçı with the notation, "Translator: Kemal Tahir." It was followed by second and third editions published by Ahmet Halit Yaşaroğlu in 1945 and 1953, respectively, and labeled as "adjusted and transferred from German by Kemal Tahir” (see fig. 3). Categorized as an 'interlingual translation’ (Öncü

\footnotetext{
${ }^{2}$ No year of publication is indicated in the two-volume edition by Semih Lûtfi which was used in this study. Other sources (Çalapala 1972, 5; Öncü 2017, 40), however, give the year of publication as "1945." The back cover of the second volume states that the first edition of the work was published thirty-seven years earlier. Calculated according to the Rumi Calendar, "1323," the year of publication of the first edition, corresponds to 1907/1908 in the Gregorian Calendar, which supports accepting "1945" as the year of publication for the Semih Lutfi edition. Therefore, the year of publication for the edition under consideration is accepted as " 1945 " in this study.

${ }^{3}$ Unless otherwise stated, all translations are mine.

${ }^{4}$ In the 1937 edition, the title of the work appears as Bir Çalgıcının Seyahatı.
} 
2017), Tahir's text was also called a "revision” (Şahin 2005, 2; Tahir Gürçağlar 2008, 228) or "summary" (Çalapala 1972, 5) of Tevfik's text. Based on the claim that Tahir performed "the adjustment and transfer not actually from German, but from Mehmet Tevfik's book" (Gündüz 2017, 39), i.e., "the work's previously published Turkish original” (Çalapala 1972, 5), this study analyzes the relationship between Tevfik's and Tahir's texts and argues that Tahir's text is an 'intralingual translation' based on the analysis of specific examples of translator decisions throughout the text.

\section{Bir Çalgıcının Seyahati within the Context of Interlingual Translation}

\subsection{Claims}

A note from the publisher entitled "Bir Çalgıcının Seyahati Hakkında Bir İzah" (An explanation of Bir Çalgıcının Seyahati) appears on the back cover of the second volume of Bir Çalgıcının Seyahati by Semih Lûtfi. This note includes the following assertion that Bir Çalgıcının Seyahati "is not a translation but an original novel and a genuine Turkish work":

The first edition of the novel Bir Çalgıcının Seyahati, which was published thirtyseven years ago and has enjoyed the highest circulation in our country, contains a notation indicating that it is a translation from German. Few of those who see this note actually know that Sultan Hamid once prohibited the publication of indigenous novels. Because of the prohibition, the author was obliged to place such a notation in the original work in order to pass it through censorship. Now, after nearly half a century, based on the strongest evidence, we can proudly announce: Bir Çalgicının Seyahati is not a translation but an original novel and a genuine Turkish work. (Tevfik 1945, back cover of vol. 2; emphasis added)

The note further explains that the reason Bir Çalgıcının Seyahati "was easily believed to be a translation" was due to the fact that "the setting and all the characters in the novel are foreign." The note states that this was the case because "these [things] are actually the Turkish author's own observations." Since Tevfik "traveled and lived in various European countries for many years, he had the opportunity to experience and observe the cities, towns, villages, characters, and customs of the Western world." In addition to this, in his preface to the Atlas edition of Bir Çalgıcının Seyahati (see fig. 4), Çalapala (1972) noted that he "wanted to uncover the identity of the text's real author," i.e., Tevfik, who was presented as the translator. Çalapala's research, however, did not yield any significant information as to who Tevfik actually was (6). Çalapala wrote: 
It was Hüseyin Kitapçı, the owner of İkbal Kütüphanesi, who published the second and third editions of the book. During a conversation between us in 1933, he said to me, "There is no original for this book. Because books translated from foreign languages were in great demand back then, Mehmet Tevfik Bey wrote this book and presented it as a translation." ${ }^{5}(5-6)$

At this point, in the context of translation studies, the concept of "pseudo translation" may come to mind. Bir Çalgıcının Seyahati was, in fact, defined as "a pseudo translation originally written by Mehmet Tevfik in Ottoman script" (Tahir Gürçağlar 2008, 228). In translation studies literature, the phenomenon of pseudo translation was first addressed by Anton Popovič through the concept of "fictitious translation" that he included in his classification of translation types (O'Sullivan 2011, 123). It was later termed "pseudo translation" by Gideon Toury (1995) and used to denote "texts which have been presented as translations with no corresponding source texts in other languages ever having existedhence [with] no factual 'transfer operations' and translation relationships" (40). ${ }^{6}$ Although we can talk about the existence of a fictitious source text formed in the mind of the pseudo translator during the production of the pseudo translation, the concept of pseudo translation is characterized by the nonexistence of any physical text serving as the source and establishing an assumed transfer relationship with the text being presented as a translation. As a matter of fact, "it is the character of pseudo translation as a reciprocal relationship between a present text and its sources, in spite of the apparent absence of the latter, that has gained ground in translation studies, in particular in Descriptive Translation Studies" (Rambelli 2009, 209). ${ }^{7}$ The following statement in the aforementioned publisher's note "Bir Çalgıcının Seyahati Hakkında Bir İzah," on the other hand, is significant in the sense that it refers, for the first time, to the existence of a possible source text for Bir Çalgıcının Seyahati: "There is a small German book reminiscent of a small passage in the novel Bir Çalgıcının Seyahati. We cannot deny that the author could have been slightly inspired by this story." Still, it was strongly emphasized that this textual similarity by no means implied a translation relationship between Bir Çalgıcının Seyahati and the obscure German work mentioned:

\footnotetext{
${ }^{5}$ Unless otherwise stated, all emphases are in the originals.

${ }^{6} \mathrm{~A}$ case of pseudo translation in the Turkish literary and cultural system was first discovered by Işın Bengi-Öner who, in her pioneering study titled "Çeviribilim, Çeviri Kuramı ve Sözde Çeviriler" ([1990] 1999; translation studies, translation theory, and pseudo translations), revealed the status of Genç Kızlar (Young girls) by Nihal Yeğinobalı as a pseudo translation and provided an analysis of it within the context of translation studies.

${ }^{7}$ For previous research on pseudo translation by Turkish translation studies scholars, see Alt 2008; Öztürk Kasar 2009; Tahir Gürçağlar 2010; Alimen 2010, 2018; Boy 2018.
} 
In addition to the fact that Bir Çalgılcının Seyahati is fifteen or twenty times longer than the German story, there is simply no connection between their titles. That is to say: the volume and titles, as well as the themes and details of both works, refute the claim that Mehmet Tevfik translated from that tiny book. (Tevfik 1945, back cover of vol. 2)

After researching the German book referenced without further detail in the publisher's note, Çalapala (1972) had this to say:

The literature teachers of German and Austrian high schools in Istanbul reported that they did not know of such a book. The veteran authors-Kemal Salih Sel, Reşat Ekrem Koçu, Münir Süleyman Çapanoğlu, Murat Sertoğlu, Tahir Alangu, and Nijat Özön-and the veteran booksellers - Seyyit Tahir and Hüseyin Tutya-whom I consulted, agreed with the rumors that this novel was an expanded rewriting of a foreign work. And Hayrullah Örs revealed the book Mehmet Tevfik Bey was inspired by. This book is Eichendorff's novella titled Aus dem Leben eines Taugenichts. (6; italics mine)

Eichendorff's work titled Aus dem Leben eines Taugenichts was published in 1826 by Vereinsbuchhandlung. ${ }^{8}$ Çalapala (1972) emphasized that nothing more than "a similarity that could only be called "inspiration"" exists between Aus dem Leben eines Taugenichts and "Mehmet Tevfik Bey's work" (6).

The relationship between Bir Çalgıcının Seyahati and Aus dem Leben eines Taugenichts is addressed by Doğan Gündüz in his review entitled "Bir Kitabın Serüveni: Bir Haylazın Hayatı'ndan Bir Çalgııının Seyahati'ne... Bir Kitabın Macerası!” (A book's journey: From Aus dem Leben eines Taugenichts to Bir Çalgıcının Seyahati... The adventure of a book!). Gündüz (2017) says:

Considering the theme, setting, and even the similarity of many events that unfold in the story, it is certain that Mehmet Tevfik was deeply inspired by Eichendorff's novel and kept it in hand as a guide while writing Bir Çalgıcının Seyahati. Nevertheless, Mehmet Tevfik produced an original novel. (39)

Regardless of these considerations, Bir Çalgıcının Seyahati was categorized under the list of translations from German into Turkish in Mehmet Öncü's (2017) Türkçe Çeviriler Bibliyografyası: Dünya Edebiyatından Çeviriler (Bibliography of Turkish translations:

\footnotetext{
${ }^{8}$ In the Turkish target system, there are two translations of Aus dem Leben eines Taugenichts presented under the German author's name. The first of these is Behçet Gönül's (Necatigil) translation entitled Bir Haylâzın Hayatı (The life of a good-for-nothing), published in 1946 by Millî Eğitim. The second is Ahmet Arpad's translation entitled Bir Çalgıcının Gezileri (The travels of a musician), published in 1975 by Neşriyat Anonim. These two translations, as well as the editions based on the text produced by Tevfik without an author's name-i.e., Atlas (1972), Sosyal (1985), Yap1 Kredi (1992), Engin (1993) — have been left out of the scope of this study.
} 
Literatures of the world in Turkish translation), with Eichendorff as author and Tevfik as translator (40), as seen in table 1 below:

Table 1. Entry no. 1169 in the list of translations from German literature into Turkish in Türkçe Çeviriler Bibliyografyası: Dünya Edebiyatından Çeviriler

\begin{tabular}{|c|c|c|c|c|}
\hline Author & Work & Translator & Year & Publisher \\
\hline $\begin{array}{c}\text { Joseph von } \\
\text { Eichendorff }\end{array}$ & Bir Çalgicının Seyahati & Mehmet Tevfik & $\begin{array}{c}1323 \\
(1945)^{9}\end{array}$ & $\begin{array}{c}\text { Semih } \\
\text { Lûtfi }\end{array}$ \\
\hline
\end{tabular}

By the same token, providing a comparative analysis of the source and target texts, Yelda Şahin took Bir Çalgıcının Seyahati as an interlingual translation in her doctoral dissertation (2005), and in her article (2012).

Based on all this, it can accurately be said that Bir Çalgıcının Seyahati has been categorized as a 'translation,' an 'original,' and a 'pseudo translation.' Assertions that Bir Çalgıcının Seyahati is not a 'translation' but an 'original' and that Tevfik is not the 'translator' but rather the 'author' are particularly based on the fact that, in comparison to Aus dem Leben eines Taugenichts, Bir Çalgıcının Seyahati has a much larger volume and includes different characters. Therefore, it has been concluded that the similarity between the two works is nothing more than 'inspiration.' Accordingly, clear boundaries were set to distinguish between 'translation' and 'original' / 'translator' and 'author' in the classification of Bir Çalgıcının Seyahati. What makes this dichotomy questionable is its possible association with a conception of translation that reduces the phenomenon to a mere linguistic transfer between the source text and the target text. Today, however, translation is defined as "no longer a phenomenon whose nature and borders are given once and for all, but an activity dependent on the relations within a certain cultural system," and "even the question of what is a translated work cannot be answered a priori in terms of an a-historical out-of-context idealized state: it must be determined on the grounds of the operations governing the polysystem" (Even-Zohar 1990, 51).

\footnotetext{
${ }^{9}$ In this entry, "1323" (1907/1908) reflects the publication year of the first Ottoman script edition of the work in book form, while " 1945 " indicates the year the same work came out in Latin script for the first time.
} 
2.2 Similarities and Differences between Bir Çalgıcının Seyahati and Aus dem Leben eines Taugenichts

In her study titled "Özgünün Kökeni ve Çeviride Telif Hakları Meselesi” (The origin of the original and the issue of translation copyright), Banu Tellioğlu (2019) sheds light on the emergence of the hierarchy between 'original' and 'translation.' She places the issue in a historical context, emphasizing the fact that until the concepts of 'authorship' and 'originality' were established, "it was not commonly believed that there are distinct differences between a work produced by an author and a translated one" (137). In fact, for centuries, the line between 'author' and 'translator' remained blurred. ${ }^{10}$ Within the medieval canon, for example, "translation served as an umbrella term that included many writing techniques such as adaptation, borrowing, expansion, reduction, compilation, and rewriting" (138). Similarly, within the Ottoman tradition:

In the hybrid aesthetics and understanding of language found in Ottoman Turkish, as well as its appropriation techniques, the source text/target text distinction was blurred, and the difference between the two became ambiguous, with the target text turning into a kind of source. When source-target texts are compared, however, dissimilarity within the similarity (i.e., areas of originality) is also noticed. ${ }^{11}$ (Paker 2014, 69)

At this point, the positioning of Bir Çalgıcının Seyahati, presented without an author's name as a German to Turkish translation, necessitates consideration of the traditional text production practices in use during the Ottoman period when the work was produced. This portion of the study will examine the relationship between Bir Çalgıcının Seyahati and Aus dem Leben eines Taugenichts. This textual examination particularly draws on examples which conceivably paved the way for arguments in favor of defining the relationship between the two texts as 'inspiration' rather than 'translation.' The three examples below will demonstrate, though, that the former may not (even does not) necessarily rule out the classification of Bir Çalgıcının Seyahati as an 'interlingual translation' within the context and tradition it was constructed in. In fact, in general, the work seems to feature what Saliha Paker (2014) calls "dissimilarity within the similarity" or "areas of originality," (69) which is an inherent characteristic within the Ottoman text production practices of that era.

\footnotetext{
${ }^{10}$ For a study contextualizing the relationship between the East and West, translatorship and authorship, and translation and original in the Turkish literary and cultural system, see Karadağ 2019.

${ }^{11}$ For more on the topic of the Ottoman understanding of translation, see also Demircioğlu 2005, 2009.
} 
Example 1

The first example below is excerpted from the beginning of the texts. In this example, the common theme of 'inspiration' is the protagonist's being "good-for-nothing." This theme, directly referred to in the title of the German text, marks the beginning of the protagonist's adventures in both texts. ${ }^{12}$

\begin{tabular}{|c|c|c|}
\hline C Çalgıcının Seya & $\begin{array}{l}\text { Bir Çalgıcının Se } \\
\text { (Translator: Tevfi }\end{array}$ & $\begin{array}{c}\text { Aus dem Leben eines } \\
\text { Taugenichts } \\
\text { (Author: Eichendorff, 1826) }\end{array}$ \\
\hline $\begin{array}{l}\text { Babam, ikide birde: } \\
\text {-Tenbel, haylaz, [. . . ] } \\
\text { derdi. [. . .], babam hiddetle } \\
\text { karşıma çıktı: } \\
\text { —-Bana bak Alfred! } \\
\text { Bugünden itibaren evimin } \\
\text { kapısı senin için kapalıdır! } \\
\text { On sekiz yaşını ikmal ettin. } \\
\text { [ . . ] Şimdi buradan çıkıp } \\
\text { gideceksin, dedi. }{ }^{13} \text { (1:3) } \\
\text { (My father always said: } \\
\text { —You lazy, good-for- } \\
\text { nothing, [. . .], my father } \\
\text { furiously appeared in front of } \\
\text { me: } \\
\text {-Look at me, Alfred! The } \\
\text { door of my house is closed to } \\
\text { you from now on! You have } \\
\text { turned eighteen. [. . .] Now, } \\
\text { get out of here.) }\end{array}$ & 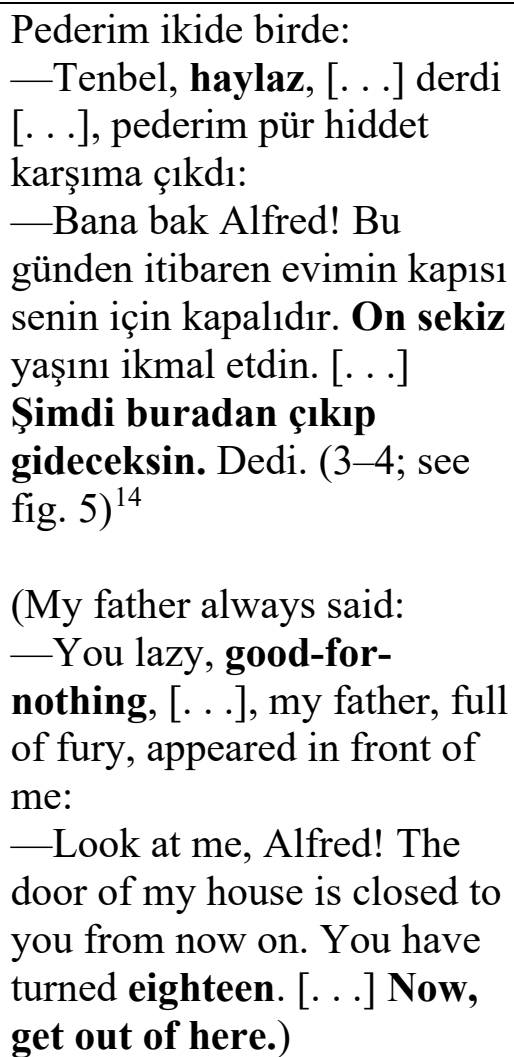 & $\begin{array}{l}\text { Da trat der Vater aus dem } \\
\text { Hause; [...], der sagte zu } \\
\text { mir: "Du Taugenichts! [...] } \\
\text { Ich kann Dich hier nicht } \\
\text { länger füttern. Der Frühling } \\
\text { ist vor der Thüre, geh auch } \\
\text { einmal hinaus in die Welt } \\
\text { und erwirb Dir selber Dein } \\
\text { Brodt." (3) } \\
\text { (Then, the father came out of } \\
\text { the house; [...], he said to } \\
\text { me: } \\
\text { "You, good-for-nothing! } \\
\text { [...] I cannot feed you here } \\
\text { anymore. Spring is at the } \\
\text { door, go out into the world } \\
\text { for once and earn your own } \\
\text { bread yourself.") }\end{array}$ \\
\hline
\end{tabular}

In this example, the protagonist-“Alfred Müller” in Bir Çalgıcının Seyahati and an anonymous character in Aus dem Leben eines Taugenichts - is thrown out of the home by his father who calls him "good-for-nothing." In both texts, this happens while the protagonist is sitting on the doorstep doing nothing: which annoys his father. One noteworthy point of difference is that, in Bir Çalgıcının Seyahati, the father emphasizes that "Alfred Müller" has

\footnotetext{
${ }^{12}$ In this part, the excerpts are shown in three columns: Bir Çalgıcının Seyahati (1945; Semih Lûtfi edition) which served as the point of departure for this study, Bir Çalgıcının Seyahati (1926), and Aus dem Leben eines Taugenichts (1826), respectively.

${ }^{13}$ Unless otherwise stated, the emphases in the excerpts are mine.

${ }^{14}$ I owe special thanks to Osman Çeviktay for his support in transcription of the excerpts from the 1926 Ottoman script edition of Bir Çalgıcının Seyahati.
} 
turned "eighteen," which means he is no longer a child and can take care of himself. In Aus dem Leben eines Taugenichts, there is no reference to the age of the protagonist. In the next part of this scene, "the violin," which is hinted at in the title of the Turkish work, stands out as a significant image. In both the Turkish and the German text, after hearing his father's words, the protagonist picks up his violin and starts off. More importantly, in the German text, the father gives him some money before he leaves home, while in the Turkish text, he cannot even ask for money from his father (who is actually not poor). Therefore, it can be argued that a relatively harsher father figure is created in the Turkish text (see Eichendorff 1826, 4; Tevfik 1926, 4 [fig. 6]; Tevfik 1945, 1:4).

\section{Example 2}

In the second example, the 'inspiration' is found in the "carriage" scene involving the protagonist's first encounter with two women. In this scene, the traveling protagonist comes across two women on a carriage ride and gets invited into their carriage. This example is significant because, in both texts, the story unfolds around the subsequent experiences of the protagonist as he chases the younger of these two women, with whom he falls in love.

\begin{tabular}{|c|c|c|}
\hline $\begin{array}{l}\text { Bir Çalgıcının Seyahati } \\
\text { (Translator: Tevfik, 1945) }\end{array}$ & $\begin{array}{l}\text { Bir Çalgıcının Seyahati } \\
\text { (Translator: Tevfik, 1926) }\end{array}$ & $\begin{array}{c}\text { Aus dem Leben eines } \\
\text { Taugenichts } \\
\text { (Author: Eichendorff, 1826) }\end{array}$ \\
\hline $\begin{array}{l}\text { Başımı çevirdim, dört atlı } \\
\text { gayet büyük bir posta } \\
\text { arabası. [. . . Y Yolcular, biri } \\
\text { yaşlı, diğeri gayet genç ve } \\
\text { güzel iki kadındı. [. . .] } \\
\text { —Arabanın üzerine çıkınız. } \\
\text { [ . . ] } \\
\text { Arabacı kamçıyı şaklattı, } \\
\text { atlar dört nala koşmağa } \\
\text { başladı. Arabanın } \\
\text { sür'atinden bir iki defa } \\
\text { başımdaki şapka az kaldı } \\
\text { yere yuvarlanacaktı. (1:4-5) } \\
\text { (I turned my head and saw a } \\
\text { large four-horse carriage. } \\
\text { [. . .] The passengers were } \\
\text { two women, one of whom } \\
\text { was old and the other was } \\
\text { young and beautiful. [. . .] }\end{array}$ & $\begin{array}{l}\text { Başımı çevirdim, dört bargirli } \\
\text { gayet cesim bir posta } \\
\text { arabası. [. . . ] Yolcular biri } \\
\text { yaşlı diğeri gayet genç ve } \\
\text { güzel iki kadından ibaret idi. } \\
\text { [ . . ] } \\
\text { —-Arabanın üzerine çıkınız. } \\
\text { [ . . ] } \\
\text { Arabacı kamçıyı şakla[t]dı, } \\
\text { bargirler dört nala koşmağa } \\
\text { başladı. Arabanın } \\
\text { sür'atinden bir iki def'a } \\
\text { başımdaki şapka az kaldı } \\
\text { yere yuvarlanacak idi. ( } 5,6 \text {, } \\
7 \text {; brackets added to correct } \\
\text { the typographical error; see } \\
\text { fig. } 7 \text { ) } \\
\text { (I turned my head and saw a } \\
\text { large four-horse carriage. }\end{array}$ & $\begin{array}{l}\text { Indem wie ich mich so } \\
\text { umsehe, kömmt ein } \\
\text { köstlicher Reisewagen ganz } \\
\text { nahe an mich heran, [. . .], } \\
\text { und zwei vornehme Damen } \\
\text { steckten die Köpfe aus dem } \\
\text { Wagen und hörten mir zu. } \\
\text { Die eine war besonders } \\
\text { schön und jünger als die } \\
\text { andere, aber eigentlich } \\
\text { gefielen sie mir alle beide. } \\
\text { [. . .] "Spring er nur hinten } \\
\text { mit auf, wir fahren auch } \\
\text { nach W." [. . .], der Kutscher } \\
\text { knallte und wir flogen über } \\
\text { die glänzende Straße fort, } \\
\text { daß mir der Wind am Hute } \\
\text { pfiff. (5) } \\
\text { (As I was looking around, a }\end{array}$ \\
\hline
\end{tabular}


transLogos 2019 Vol 2 Issue 2

Boy, Hülya, pp. 70-101

(Re)Positioning of Inter- and Intra-Lingual

Translational Adventures

\begin{tabular}{|c|c|c|}
\hline $\begin{array}{l}\text {-Get on the carriage! } \\
{[\ldots]} \\
\text { The coachman flicked the } \\
\text { whip, the horses started to } \\
\text { gallop. The hat on my head } \\
\text { nearly tumbled to the } \\
\text { ground once or twice } \\
\text { because of the carriage's } \\
\text { speed.) }\end{array}$ & $\begin{array}{l}{[\ldots] \text { The passengers were }} \\
\text { two women, one of whom } \\
\text { was old and the other was } \\
\text { young and beautiful. [...] } \\
\text {-Get on the carriage! } \\
{[\ldots]} \\
\text { The coachman flicked the } \\
\text { whip, the horses started to } \\
\text { gallop. The hat on my head } \\
\text { nearly tumbled to the } \\
\text { ground once or twice } \\
\text { because of the carriage's } \\
\text { speed.) }\end{array}$ & $\begin{array}{l}\text { delightful carriage [...] } \\
\text { drew close to me, and two } \\
\text { noble ladies poked their } \\
\text { heads out of the carriage and } \\
\text { listened to me. One of them } \\
\text { was especially beautiful and } \\
\text { younger than the other, but } \\
\text { I actually liked both of them. } \\
\text { [ . . . "Jump up behind the } \\
\text { carriage, we are also going } \\
\text { to W." [...], the coachman } \\
\text { flicked the whip, and we flew } \\
\text { over the shiny street so fast } \\
\text { that the wind was whistling } \\
\text { round my hat.) }\end{array}$ \\
\hline
\end{tabular}

In the relevant scene, certain parts of which are excerpted here, the similarity between the two texts is reflected particularly where the two women praise the protagonist for his ability to play the violin and sing beautifully. They talk between themselves in a foreign language which the protagonist does not understand and then invite him to accompany them. He accepts their invitation and climbs onto the carriage, which then gallops away towards the "chateau." In the German text, when asked where he is going, the protagonist replies "to W." (Wien), but in the Turkish text, he says he actually does not know where to go. Later, though, the protagonist and the two women set off for Wien.

Example 3

When the texts are compared, the "chateau" can also be seen as providing thematic 'inspiration.' The excerpts in the third example are taken from the section where the protagonist and the two women arrive at the "chateau" at the end of their carriage ride.

\begin{tabular}{|c|c|c|}
\hline $\begin{array}{l}\text { Bir Çalgıcının Seyahati } \\
\text { (Translator: Tevfik, 1945) }\end{array}$ & $\begin{array}{l}\text { Bir Çalgıcının Seyahati } \\
\text { (Translator: Tevfik, 1926) }\end{array}$ & $\begin{array}{c}\text { Aus dem Leben eines } \\
\text { Taugenichts } \\
\text { (Author: Eichendorff, 1826) }\end{array}$ \\
\hline $\begin{array}{l}\text { Köyden açıldıktan yirmi } \\
\text { dakika sonra araba gayet } \\
\text { büyük bir kapıdan içeri girdi, } \\
\text { Mikaella: } \\
\text { —İşte şato Mösyö Alfred } \\
\text { Müller! dedi. } \\
\text { Avrupada gayet büyük } \\
\text { binalara şato dendiğini }\end{array}$ & $\begin{array}{l}\text { Köyden açıldıktan yirmi } \\
\text { dakika sonra araba gayet } \\
\text { büyük bir kapıdan içeri girdi, } \\
\text { Mikaella: } \\
\text { —İşte şato mösyö Alfred } \\
\text { Müller! dedi. } \\
\text { Avrupada gayet cesim binalar } \\
\text { şato tesmiye idildiğini }\end{array}$ & $\begin{array}{l}\text { Als ich die Augen aufschlug, } \\
\text { stand der Wagen still unter } \\
\text { hohen Lindenbäumen, hinter } \\
\text { denen eine breite Treppe } \\
\text { zwischen Säulen in ein } \\
\text { prächtiges Schloß führte. (6) } \\
\text { (When I opened my eyes, the }\end{array}$ \\
\hline
\end{tabular}


transLogos 2019 Vol 2 Issue 2

Boy, Hülya, pp. 70-101

A Translation Studies Journal

(Re)Positioning of Inter- and Intra-Lingual

(C) Diye Global Communications Translational Adventures diye.com.tr|diye@diye.com.tr

\section{biliyordum. Bunun için \\ Matmazel Mikaellanın bahsettiği şatonun da süslü, büyük, âdeta elli, altmış odalı bir konak olduğunu evvelden anlamıştım. (1:30)}

(Twenty minutes away from the village, the carriage passed through a rather big gate and Mikaella said: -Here is the chateau, Monsieur Alfred Müller! I knew that such big buildings were called 'chateaus' in Europe. Therefore, I had already understood that the chateau Madamoiselle Mikaella mentioned was an ornate, large mansion with about fifty or sixty rooms.)

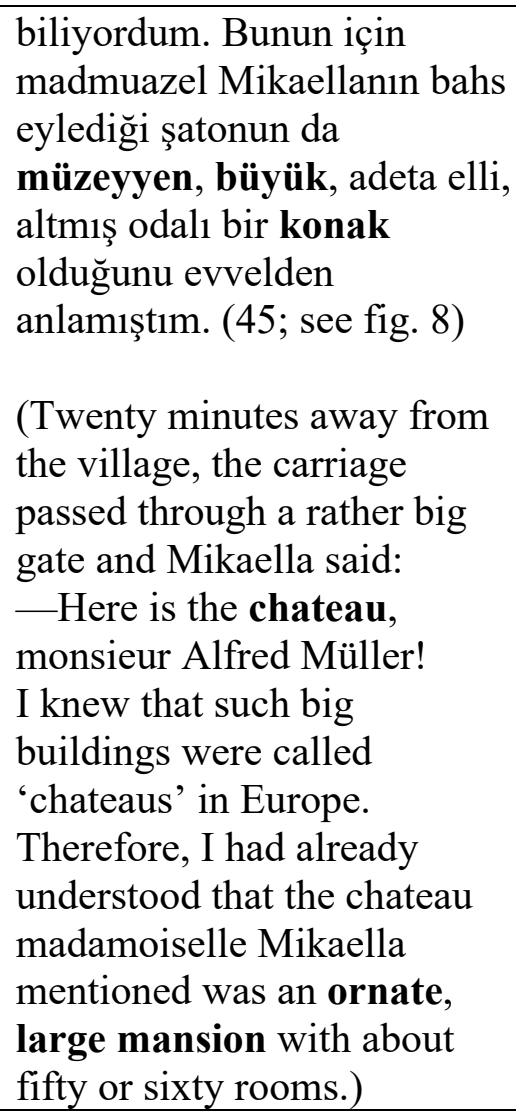

carriage had stopped under tall lime trees beyond which broad stairs between pillars led up to a splendid chateau.)

In this example, the German text describes the "chateau" as "prächtig" (splendid), and the Turkish text describes it as "süslü" (ornate) and "büyük" (large), as well as associating it with the "konak" (mansions) within the context of the target culture. Furthermore, in both texts, the former "fare collector"-whose name is "Tom" in the Turkish text but who remains unnamed in the German text-had died a short while ago and left his position vacant. Therefore, after being asked if he knows how to read and write, the protagonist is appointed as the new "fare collector" of the "chateau" (see Eichendorff 1826, 16-17; Tevfik 1926, 5152 [fig. 9]; Tevfik 1945, 1:34).

A thorough analysis of the textual examples, including but not limited to the ones provided here, leads to the conclusion that Tevfik produced Bir Çalgıcının Seyahati as an 'interlingual translation' by making use of the Ottoman text production practices common among authors of the time who used "additions, omissions, and enrichment from different sources, at their own discretion" (Paker 2014, 43). That is, they produced works "from the sources they had, using a variety of methods and resorting to alterations" (44). Paker also underscores that "in time, the texts the authors produced through these means ended up serving as source texts for others" (43). It can reasonably be claimed that Tevfik's 
'interlingual translation,' Bir Çalgıcının Seyahati, itself served as the source text for an 'intralingual translation.' Given that, the work will be analyzed from the standpoint of intralingual translation in the following section of the study.

\section{Bir Çalgıcının Seyahati within the Context of Intralingual Translation}

\subsection{Claims}

In addition to the claim that Bir Çalgıcının Seyahati "is not a translation but an original novel," the aforementioned note from the publisher includes this second assertion:

Semih Lûtfi owns all rights to the novel Bir Çalgıcının Seyahati. Despite this, some have not shied away from taking credit for publishing this sizeable work in a ridiculous form: reducing it to less than one fifth of its original size. This miniscule book, with its arms and legs ripped off is allegedly a translation from the original of the work! Yet there is neither an original of the work, nor does this claim have any grounds... Furthermore, the ridiculous book created by cutting and trimming the text of Bir Çalgıcının Seyahati (printed in full by our publishing house) has turned out to be a peacock plucked of its wing and tail feathers. (Tevfik 1945, back cover of vol. 2; emphasis added)

The book addressed in a contemptuous manner here is Bir Çalgıcının Seyahatı bearing Tahir's name as the translator. The first edition of this book was published in 1937 by Yeni Kitapçı, as the fourth book of its Cheap Novel Series. Bearing only the inscription, "Translator: Kemal Tahir," it came out without an author's name or the title of the original. The second and third editions of this work were published by Ahmet Halit Yaşaroğlu in 1945 and 1953, respectively, with a note that read "adjusted and transferred from German by Kemal Tahir.” The work was categorized as an ‘interlingual translation' by Öncü $(2017,40)$ :

Table 2. Entry no. 1167 in the list of translations from German literature into Turkish in Türkçe Çeviriler Bibliyografyası: Dünya Edebiyatından Çeviriler

\begin{tabular}{|c|c|c|c|c|}
\hline Author & Work & Translator & Year & Publisher \\
\hline $\begin{array}{c}\text { Joseph von } \\
\text { Eichendorff }\end{array}$ & Bir Çalgıcının Seyahati & Kemal Tahir & $1953^{15}$ & $\begin{array}{c}\text { Ahmet Halit } \\
\text { Yaşaroğlu }\end{array}$ \\
\hline
\end{tabular}

\footnotetext{
${ }^{15}$ Regarding the method followed in the preparation of the lists included in the bibliography, the following statement was made: "We took into consideration only the first edition of each work and did not add the other editions of the same work belonging to the same translator and publishing house to the list. Apart from this, in cases where the same work was translated by a different translator or published by a different publishing house, the related work was added to the list as a new one" (Öncü 2017, 7). In this entry, however, the given publication year corresponds to that of the third edition of Tahir's work.
} 
Çalapala (1972) referred to the books bearing Tahir's name as Bir Çalgıcının Seyahati's "editions published in a quite abridged form that we could call 'summary"” (5). He describes Tahir's interaction with the related texts as follows:

According to the information we received from Kemal Tahir, this novel is an indigenous work written off of inspiration from a German book. The book bearing Kemal Tahir's name benefited from the Turkish original which precedes it. Kenan Sertel, the owner of Yeni Kitapçı establishment, asked Kemal Tahir to simplify the language of this book and to abridge it a little. Tahir abridged this book to nearly one fourth of its length and altered some parts of it. Recalling the process, our famous novelist laughed out loud and said, "There is a priest in the novel. My Islamic side incited me to turn him into a carpenter." Tahir's name appeared on the book through a fait accompli by the publisher without his knowledge. (Çalapala 1972, 5; italics mine)

Considering the statements below, written by Tahir in his May 9, 1937 letter to Fatma İrfan Serhan, one can conclude he was actually uncomfortable with the fact that Bir Çalgııının Seyahati came out in his name.

The book [Bir Çalgıcının Seyahatı] I am sending along with my letter should not have been the first work by Kemal Tahir. Whenever I see it, I feel almost ashamed of myself. But that is just the way it goes, İrfan. They said it is a matter of gifting and that I am gifted for comedy rather than tragedy, so touching works should not be expected from a man playing Karagöz in Bâb-1 Âli and writing stories, jokes, and novels (!) for Karikatür magazine. ... I wonder what you will think of Bir Çalgıcının Seyahati? This novel is well known by you. Pay attention to the plain language. Let's see whether I am as gifted for writing humorous novels as the publisher claims. (Serhan 1979, 184)

These statements by Tahir seem to indicate that his hesitation about being presented as the translator of Bir Çalgıcının Seyahatı stems from the 'humorous' nature of the novel rather than the "fait accompli" (Çalapala 1972, 5) by the publisher. Indeed, in Yalnızız (We are lonely) by Peyami Safa ([1951] 2018), Bir Çalgıcının Seyahati was referred to as an "entertaining novel" (298). Furthermore, in Yeni Sabah's note titled "Yeni Tefrikamız Bir Çalgıcının Seyahati" (Our new serial Bir Çalgıcının Seyahati) ${ }^{16}$ introducing the novel anonymously serialized between July 7, 1940 and April 1, 1941, they praised its "amusing," "entertaining" nature, as seen below:

In these black wartime days when distressing war news and harrowing propaganda pitches destroy all joy and cheer, Bir Çalgıcının Seyahati will be welcomed by readers of every sort with delight, interest, and laughter, helping them forget the sufferings of

\footnotetext{
${ }^{16}$ This serial is based on Tevfik's text.
} 
the universal disaster for at least a little while. Bir Çalgıcının Seyahati is a work which amused and entertained a wide audience, aroused interest and appreciation for its moral value when it was published thirty years ago. Today, by permission of the publisher, Yeni Sabah is serializing Bir Çalgıcının Seyahati. The hilarious adventures in this serial will make you burst into laughter and ponder the characters' antics with delight from beginning to end. Start reading, and you will automatically understand just how true our claim is. (Yeni Sabah, 1)

The text produced by Tahir, who was apparently ashamed of being known as a translator/author of popular literature, was also identified as a "revis[ion]" of the "pseudo translation originally written by Mehmet Tevfik in Ottoman script” (Tahir Gürçağlar 2008, 228). Şahin (2005) also classifies Tahir's text as a "revision” (2) of Tevfik's 'interlingual translation.' She positions the text by Tahir as the "Target Text 2," with Aus dem Leben eines Taugenichts as the "Source Text." ${ }^{17}$ In addressing the note on the 1945 and 1953 editions of Bir Çalgıcının Seyahati that reads "adjusted and transferred from German by Kemal Tahir," Gündüz (2017) also stresses that Tahir performed "the adjustment and transfer, not actually from German, but from Mehmet Tevfik's book." He asserts that what Tahir did was "shorten" and "condense" the text, make additions and changes, and replace old words with new ones (39). These are the claims which necessitate an analysis of the relationship between the two works within the context of intralingual translation.

\subsection{Similarities and Differences between Kemal Tahir's and Mehmet Tevfik's Texts}

Considering the predisposition of Tahir's effort to "increase the dose of humor" (Gündüz 2017, 39), as well as his ideology-driven additions, omissions, and changes throughout the text, it does not seem possible to regard the text he produced as a "summary" (Çalapala 1972, 5) in the ordinary sense. Therefore, the present study positions Tahir's text as an 'intralingual translation,' 18 based on a selection of examples examined in this section as well as others not included here.

The four examples below reflect different kinds of exaggeration practiced by Tahir, mainly at two different levels, in his 'intralingual translation.' While the first two examples of

\footnotetext{
17 Şahin's (2005) positioning of her research materials is as follows: Aus dem Leben eines Taugenichts (Eichendorff 1826): Source Text; Bir Çalgıcının Seyahati (Tevfik 1926): Target Text 1; Bir Çalgıcının Seyahatı (Tahir 1937): Target Text 2; Bir Çalgıcının Seyahati (Tahir 1945): Target Text 3; Bir Haylâzın Hayatı (Gönül 1946): Target Text 4 (196).

${ }^{18}$ For recent studies on intralingual translation within the context of the Turkish literary and cultural system, see Berk Albachten 2013, 2015, 2019; Baydere 2019; Baydere and Karadağ, 2019; Kalem Bakkal 2019; Öztürk Baydere 2019.
} 
exaggeration could be associated with ideological factors (pertaining to the translator, in this case), the other two could be associated with what André Lefevere calls the "status component," which reveals Tahir's "[a]cceptance of patronage, impl[ying] integration into a certain support group and its lifestyle" (Lefevere 1992, 16).

\section{Example 1}

First of all, Tahir's decision, highlighted in the excerpt below, to turn the "priest" in the novel into a "carpenter" was driven by his Islamic faith, as he himself acknowledges. This can be regarded as one of the remarkable examples of the translator decisions shaped by ideological factors in the text.

\begin{tabular}{|c|c|c|}
\hline & & $\begin{array}{l}a t i \\
945)\end{array}$ \\
\hline $\begin{array}{l}\text { - Teşekkür ederiz mösyö! } \\
\text { Fakat siz kimsiniz? [. . .] } \\
\text { _ . . .] Ben bu köyün } \\
\text { rahibiyim. } \\
{[\ldots]} \\
\text { - . Saçlarınızın uzunluğu, } \\
\text { karnınızın büyüklüğü ve şu } \\
\text { köşede asılı duran salib bir } \\
\text { rahib olduğunuzu meydana } \\
\text { koymağa kafi. (391-392; see } \\
\text { fig. 10) } \\
\text { (-Thank you, monsieur! But } \\
\text { who are you? [. . .] } \\
\text { - . . .] I am the priest of } \\
\text { this village. } \\
\text { [. . .] } \\
\text {-The length of your hair, the } \\
\text { size of your belly, and the } \\
\text { cross hanging in that corner } \\
\text { are enough to reveal that you } \\
\text { are a priest.) }\end{array}$ & $\begin{array}{l}\text { goz lyı mı olur? (104) } \\
\text { nter's tools hung on } \\
\text { 1. So, the man who } \\
\text { d us in his home must } \\
\text { rpenter. What a kind- } \\
\text { d man! } \\
\text { diately asked: } \\
\text { you a carpenter? } \\
\text {, there was a good }\end{array}$ & 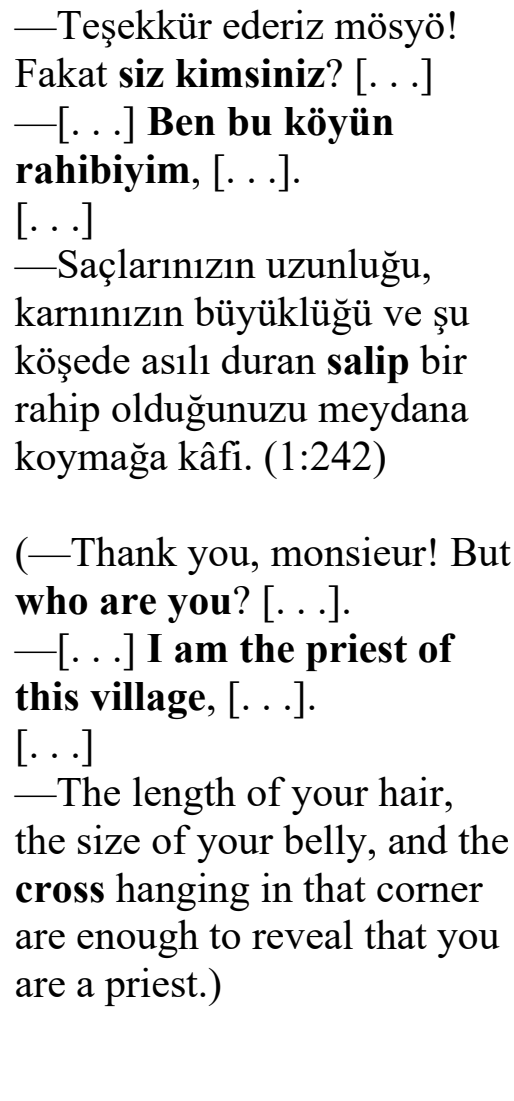 \\
\hline
\end{tabular}

In this example, by turning the "priest" into a "carpenter," Tahir transfers the goodwill mission of the "priest" to the "carpenter," who becomes the character who opens up his house to "Alfred Müller" and "Frederih Şüller," welcomes them with open arms, provides them with food, and refuses the money they offer in return for his help. The "cross" mentioned in 
Tevfik's text was translated as “carpenter's tools" by Tahir, in keeping with his decision to translate "priest" as "carpenter." Finally, while the "priest" is characterized by "kindheartedness" and "generousness" in Tevfik's text (see Tevfik 1926, 400 [fig. 11]; Tevfik 1945, 1:247), Tahir attributes these characteristics not to a "priest" but to a "carpenter" (see Tahir 1937, 104).

\section{Example 2}

The second example is an excerpt from the part where "Alfred Müller," about to be married to a girl from the village against his will, eludes the "priest" and the village folk by fleeing.

\begin{tabular}{|c|c|c|}
\hline $\begin{array}{c}\text { Bir } \\
\text { (Tran }\end{array}$ & $\begin{array}{r}\text { Bir } \\
\text { (Tra }\end{array}$ & $\begin{array}{c}\text { Bir } \\
\text { (Tran }\end{array}$ \\
\hline $\begin{array}{l}\text { Köy rahibi gayet iyi bir } \\
\text { adam olmalı ki: } \\
\text { —Çocuklar, bırakınız şu } \\
\text { çapkını! Etdiği ile kalsın. } \\
\text { [. . .] dedi. (150; see fig. } 12 \text { ) } \\
\text { (The priest of the village } \\
\text { must have been a pretty } \\
\text { good man, as he said: } \\
\text {-Guys, please leave that } \\
\text { heartbreaker alone! Let him } \\
\text { get away with what he did.) }\end{array}$ & $\begin{array}{l}\text { Papasa gelince: } \\
\text { —Dinsiz herif! İmansız } \\
\text { herif, öldürün, kanı helâldır } \\
\text { diye fetva veriyordu. (48) } \\
\text { (As for the priest, he was } \\
\text { giving fatwa: } \\
\text { - Irreligious guy! Faithless } \\
\text { guy! Kill him; his blood is } \\
\text { halal.) }\end{array}$ & $\begin{array}{l}\text { Köy rahibi gayet iyi bir } \\
\text { adam olmalı ki: } \\
\text { —Çocuklar, bırakın şu } \\
\text { çapkını! Ettiği ile kalsın. } \\
\text { [ . . .] dedi. (1:96) } \\
\text { (The priest of the village } \\
\text { must have been a pretty } \\
\text { good man, as he said: } \\
\text {-Guys, please leave that } \\
\text { heartbreaker alone! Let him } \\
\text { get away with what he did.) }\end{array}$ \\
\hline
\end{tabular}

In this example, it is clear that Tahir preferred to translate the reaction of the "priest" so that he turns out to be, not a soother, as in Tevfik's text, but a provoker: urging the others to go after "Alfred Müller" and kill him. He thereby portrays the "priest" as a ruthless person.

In general, Tahir's decisions in other parts of the book, including references to the qualifications of a "priest" such as being wise, instructive, and guiding, are also in line with the ones depicted above. For instance, where the good features of a "priest" are mentioned, Tahir chose to translate "priest" as "teacher" (see Tevfik 1926, 3 [fig. 13]; Tahir 1937, 3; Tevfik 1945, 1:3) or made omissions so as not to mention a "priest" at all (see Tevfik 1926, 11 [fig. 14]; Tahir 1937, 5; Tevfik 1945, 1:8). 
These examples show that the exaggeration in the intralingual translation here is predominantly surrounding the "priest" figure which is portrayed positively by Tevfik but either translated negatively or eliminated altogether by Tahir.

\section{Example 3}

The third example is from the scene where, in Tevfik's translation, "Alfred Müller" is being clumsy while eating at a restaurant together with his friend "Frederih Şüller." As he tries to use a fork, which he finds difficult, he suddenly drops the whole chicken from the fork onto the table.

\begin{tabular}{|c|c|c|}
\hline $\begin{array}{c}\text { Bir Çalgıcının Seyahati } \\
\text { (Translator: Tevfik, 1926) }\end{array}$ & $\begin{array}{l}\text { Bir Çalgıcının Seyahatı } \\
\text { (Translator: Tahir, 1937) }\end{array}$ & $\begin{array}{c}\text { Bir Çalgıcının Seyahati } \\
\text { (Translator: Tevfik, 1945) }\end{array}$ \\
\hline $\begin{array}{l}\text { İkincide piliç çataldan } \\
\text { kurtuldu. Masanın üzerine } \\
\text { düşdü. (285-286; see fig. 15) } \\
\text { (On the second try, the } \\
\text { chicken slipped from the } \\
\text { fork and dropped onto the } \\
\text { table.) }\end{array}$ & $\begin{array}{l}\text { Çatalı piliç kızartmasına } \\
\text { saplamağa çalışırken mel'un } \\
\text { piliç tabaktan fırlayıp } \\
\text { karşımızdaki masada } \\
\text { oturan bir madamın } \\
\text { kucağına fırlamaz mı? } \\
\text { Frederihi madamın } \\
\text { yanı[n]daki müsyünün } \\
\text { elinden kurtarıncaya kadar } \\
\text { akla karayı seçtim. (76; } \\
\text { brackets added to correct the } \\
\text { typographical error) } \\
\text { (While he was trying to stick } \\
\text { the fork into the roasted } \\
\text { chicken, the damned } \\
\text { chicken flew out of the plate } \\
\text { and onto the lap of a } \\
\text { madam sitting at the table } \\
\text { opposite us! I had the devil } \\
\text { of a job saving Frederih from } \\
\text { the hands of the monsieur } \\
\text { next to the madam.) }\end{array}$ & $\begin{array}{l}\text { İkincide piliç çataldan } \\
\text { kurtuldu, masanın üzerine } \\
\text { düştü. (1:179) } \\
\text { (On the second try, the } \\
\text { chicken slipped from the } \\
\text { fork and dropped onto the } \\
\text { table.) }\end{array}$ \\
\hline
\end{tabular}

In Tahir's text, the person creating the scene is not "Alfred Müller" but "Frederih Şüller." While "Frederih" is trying to stick the fork into it, his chicken flies off his plate and into the lap of a "madam" sitting at an adjacent table. Tahir likely thought the event would sound 'funnier' to the readers recounted this way. 
Example 4

The excerpt below includes the response by "Alfred Müller" during a quarrel with a man who asks "Alfred" to excuse his wife's words because she is still "almost a child." Tahir's translation of this scene provides another example of his alterations to the text for the purpose of introducing 'humor.'

\begin{tabular}{|c|c|c|}
\hline $\begin{array}{c}\text { Bir Çalgıcının Seyahati } \\
\text { (Translator: Tevfik, 1926) }\end{array}$ & $\begin{array}{l}\text { Bir Çalgıcının Seyahatı } \\
\text { (Translator: Tahir, 1937) }\end{array}$ & $\begin{array}{c}\text { Bir Çalgıcının Seyahati } \\
\text { (Translator: Tevfik, 1945) }\end{array}$ \\
\hline $\begin{array}{l}\text {-Ne söylüyorsunuz mösyö? } \\
\text { Karınız çocuk olur mu? } \\
\text { Ben, on sekiz yaşında } \\
\text { olduğum halde koca herif } \\
\text { diyorlar. Madam en aşağı } \\
\text { kırk yaşında var. Dedim. } \\
\text { (445-446; see fig. 16) } \\
\text { (-What are you talking } \\
\text { about, monsieur? How on } \\
\text { earth can your wife be a } \\
\text { child? They call me a big } \\
\text { guy, even though I'm only } \\
\text { eighteen. The madam is at } \\
\text { least forty years old.) }\end{array}$ & $\begin{array}{l}\text { Vay kart karıyı bize göz } \\
\text { göre [gö]re genç diye } \\
\text { yutturuyorlar ha! Durur } \\
\text { muyum: } \\
\text { - Aman müsyü, siz o } \\
\text { martavalları başkasına } \\
\text { anlatın karınız ferah ferah } \\
\text { kırk yaşını aşmış elliye } \\
\text { merdiven dayamış. (123; } \\
\text { brackets added to correct the } \\
\text { typographical error) } \\
\text { (Oh, they are openly } \\
\text { fobbing off the aged dame } \\
\text { as young on us, uh? I } \\
\text { immediately answered back: } \\
\text { - Come on, monsieur; spin } \\
\text { that yarn to someone else. } \\
\text { Your wife is easily over } \\
\text { forty and pushing fifty.) }\end{array}$ & $\begin{array}{l}\text {-Ne söylüyorsunuz mösyö? } \\
\text { Karınız çocuk olur mu? } \\
\text { Ben, on sekiz yaşımda } \\
\text { olduğum halde koca herif, } \\
\text { diyorlar. Madam en aşağı } \\
\text { kırk yaşında var, dedim. } \\
(1: 274) \\
\text { (-What are you talking } \\
\text { about, monsieur? How on } \\
\text { earth can your wife be a } \\
\text { child? They call me a big } \\
\text { guy even though I'm only } \\
\text { eighteen. The madam is at } \\
\text { least forty years old.) }\end{array}$ \\
\hline
\end{tabular}

What especially stands out in this example as evidencing the translator's decision to make the text sound 'funnier' is the fact that Tahir found it appropriate to translate the part where the woman's estimated age is mentioned by using slang expressions such as, "they are openly fobbing off the aged dame as young on us" and "spin that yarn to someone else, your wife is easily over forty and pushing fifty."

These two examples demonstrate that Tahir's exaggeration in the intralingual translation arguably results from the expectations of the publisher who wanted him to produce, not only a "simplified" and "abridged" text (Çalapala 1972, 5), but also a more 'humorous' one.

In summary, the inter- and intra-lingual translations of Bir Çalgıcının Seyahati display both different forms and degrees of manipulation within translator decisions as well as their 
possible motivations. ${ }^{19}$ While the work's interlingual translational adventure analyzed in the previous section seems to portray manipulation shaped primarily by historical and contextual factors, its intralingual translational counterpart analyzed in this section can be said to represent manipulation grounded in the translator's ideology and the "status component" of "patronage" (Lefevere 1992). Lefevere (2014) points out that "acceptance of patronage may simply mean integration into the lifestyle of a support group or subculture, which certainly need not always be described in terms of an élite" (227-228). Through this acceptance, "the writer achieves a certain position in society," which is known as the "status component" of "patronage" (Lefevere 1982, 6). Acting out of what were, arguably, economic concerns, Tahir may have accepted the publisher's patronage and, therefore, crafted the intralingual translation of Bir Çalgıcının Seyahati with a higher degree of humor. That being said, it should also be acknowledged that when Tahir was commissioned by the publisher, he was assured that the work would not bear his (real) name: a fact confirmed by his letter to Fatma İrfan Serhan and by Çalapala's statements. On the other hand, it also seems clear that, within the publishing community, his name was already associated with popular/low literature, which may have led the publisher to turn to him for the job in the first place. This, in turn, made him act in line with the expectations placed on him as a writer of "stories, jokes, and novels (!) for Karikatür magazine" who was "gifted for comedy rather than tragedy" (Serhan 1979, 184). Taken together, these factors seem to have resulted in the aforementioned "fait accompli" (Çalapala 1972, 5) by the publisher. By accepting patronage, Tahir confirmed his status as a translator/author of popular literature - which he seems to find discrediting - as observable in his words below:

I have completely gotten used to my new shell. I have simply become a "funny man." We humans get used to anything. Recently, we have been preparing a series of crime fiction and cinema novels together with Nâzım [Hikmet]. In the meantime, I have to produce a series of funny novels on my own. (Serhan 1979, 184)

\section{Concluding Remarks}

In this study, the work titled Bir Çalgıcının Seyahati, which was originally presented to the Turkish literary and cultural system as an 'interlingual translation' and later served as the source text for an 'intralingual translation,' was analyzed within the context of its

\footnotetext{
${ }^{19}$ For a small-scale analysis of ideologically-driven translator decisions exclusively within the context of the intralingual translation of Bir Çalgıcının Seyahati, see Boy 2019.
} 
translational adventure. It can be suggested that the arguments surrounding the work attributed to Tevfik as 'translator' point to an existing perception of the nature of 'translation' and 'original' as binary oppositions. While there are studies in which Tevfik's work was analyzed and categorized as an 'interlingual translation' from German into Turkish (Şahin 2005; Şahin 2012; Öncü 2017), Bir Çalgıcının Seyahati was also classified as a "pseudo translation" (Tahir Gürçağlar 2008, 228). Technically defined, the concept of "pseudo translation" includes the absence of any "corresponding source texts in other languages" serving as the basis for the text presented as translation and, thus, the absence of any "factual 'transfer operations' and translation relationships" (Toury 1995, 40). Nevertheless, in the case addressed in this study, it is obvious that Eichendorff's work, Aus dem Leben eines Taugenichts, served as a source text for Bir Çalgıcının Seyahati. A historical perspective on the concepts of 'translation' and 'original' could provide insight into the controversy surrounding the classification of Bir Çalgıcının Seyahati by accounting for a different understanding of "terceme" and "te'life" in the period when the work was first introduced to the target system and the concepts of "translation" and "original" today (Paker 2014). Bir Çalgıcının Seyahati was presented to the Turkish literary and cultural system for the first time during the reign of Abdul Hamid II (1876-1909), 34th Sultan of the Ottoman Empire. While the boundaries between "terceme" and "te'lif" were blurred within the Ottoman period, today, "translation" and "original" are widely viewed as being in binary opposition (Paker 2014, 38). Therefore, it can be argued that the diverse positionings at play in the case of Bir Çalgıcının Seyahati are linked to this distinction.

In her study “Terceme, Te'lîf ve Özgünlük Meselesi” (The issue of terceme, te’liff, and originality), Paker (2014) notes that, within the Ottoman tradition, "te'liff is a work which is based on a source or sources deemed mostly foreign; it may be partly terceme or partly produced with the contributions of the author." On the other hand, "original, in the contemporary sense, is a work accepted to have been produced entirely by the author on her/his own" (38). Paker agrees with Agâh Sırrı Levend's recommendation that to "prevent young generations from confusing the two traditions of transfer, one of which is old and the other new/modern," it's important to note that "in our old literature, 'terceme' bears a broad meaning going beyond 'translation' in the contemporary sense" (41). She says that "terceme does not amount to "çeviri' ('translation')" and regards "çeviri" ("translation") as "an 
insufficient term separated from the tradition it belongs to" (68). She goes on to explain how "terceme" "goes beyond 'çeviri' ('translation') in the contemporary sense" as follows:

Terceme included both a "word for word" transfer from one language to another and the production of a text by reduction or expansion through following the source text to some extent while also tapping into either the personal views of the translator or other sources (i.e., a tradition of rewriting). The traditional Ottoman understanding of terceme, which pointed to a difference or shift from the source text and included a wide range of rewriting practices, was different from the modern understanding of çeviri (translation), which involves the dominant/canonized norm of 'absolute faithfulness to the source text.' (42)

In light of this information, the relationship between Bir Çalgıcının Seyahati and Aus dem Leben eines Taugenichts can be associated with "terceme" as part of the text production practices the target text is related with. Accordingly, Tevfik produced the translation titled Bir Çalgıcının Seyahati in the early twentieth century, tying his work to the source text "by certain relationships, some of which could be regarded . . . as necessary and/or sufficient" (Toury 1995, 35) in the target Ottoman culture. That being the case, this study first scrutinized the relationship between Tevfik's and Eichendorff's texts from the standpoint of interlingual translation, examining textual examples which may have paved the way for claims that Bir Çalgıcının Seyahati was 'inspired' by Aus dem Leben eines Taugenichts. The work was then analyzed in the context of intralingual translation, by considering assertions that Tevfik's translation Bir Çalgıcının Seyahati served as the source for a text attributed to Tahir as translator. Based on the analysis of the translator decisions and the possible motivations for such decisions through the examples chosen from the texts, the study concluded that Tahir's work can be positioned as an 'intralingual translation' within the context of translation studies. 


\section{Appendices}

Figure 1. Top to bottom: Covers of 1907/1908 [1323] (2 vols.), 1921 [1337], and 1926

Ottoman script editions of Bir Çalgıcının Seyahati

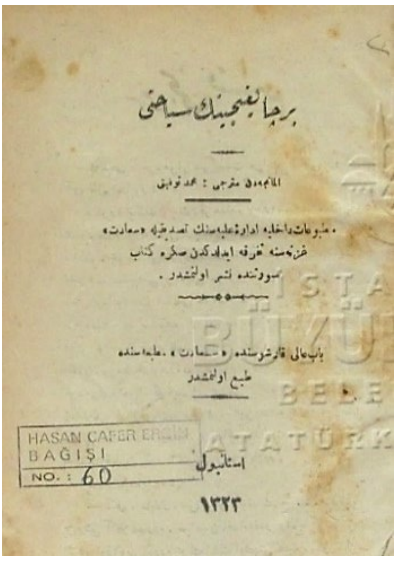

Bir Çalgıcının Seyahati

Almancadan Mütercimi: Mehmed Tevfik

Matbuat-1 Dâhiliye İdare-i 'Aliyesi'nün tasdîkiyle

"Saadet"

gazetesine tefrika idüldükden sonra kitab

suretinde neşr olınmışdur.

Bâb-1 'Alî karşusında "Saadet" matbaasında

tab' olınmışdur

İstanbul

1323

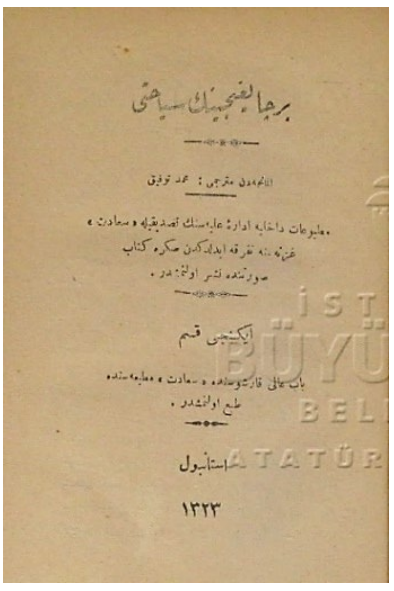

Bir Çalgıcının Seyahati

Almancadan Mütercimi: Mehmed Tevfik

Matbuat-1 Dâhiliye İdare-i 'Aliyesi'nün tasdîkiyle

"Saadet"

gazetesine tefrika idüldükden sonra kitab suretinde neşr olınmışdur.

İkinci Kısım

Bâb-1 'Alî karşusında "Saadet" matbaasında

tab' olınmışdur

İstanbul

1323

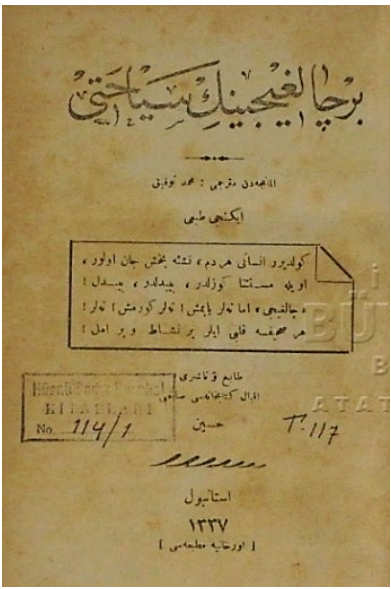

\section{Bir Calgıcının Seyahati}

Almancadan Mütercimi: Mehmed Tevfik

İkinci tab'1

Güldürür insanı her dem, neş'e-bahş-1 cân olur,

Öyle müstesnâ güzeldür, bî-bedeldür, bî-bedel!

"Çalgıcı" ama neler yapmış! Neler görmüş! Neler!

Her sahîfe kalbi eyler pür-neşât ve pür-emel!

Tâbi' ve nâşiri

İkbal Kitâbhanesi Sahibi

Hüseyin

İstanbul

1337

[Orhaniye Matba'as1] 


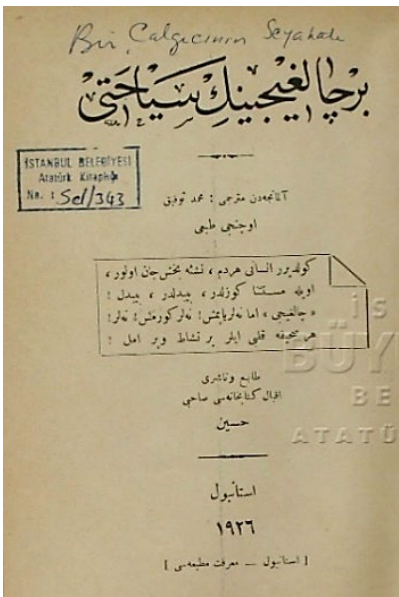

Bir Çalgıcının Seyahati

Almancadan Mütercimi: Mehmed Tevfik

Üçüncü tab'1

Güldürür insanı her dem, neş'e-bahş-1 cân olur,

Öyle müstesnâ güzeldür, bî-bedeldür, bî-bedel!

"Çalgıcı" ama neler yapmış! Neler görmüş! Neler!

Her sahîfe kalbi eyler pür-neşât ve pür-emel!

Tâbi' ve nâşiri

İkbal Kitâbhanesi Sahibi

Hüseyin

İstanbul

1926

[İstanbul - Marifet Matba’ası]

Figure 2. Left to right: Front and inner covers of vol. 1 and vol. 2 of Bir Çalgıcının Seyahati (1945; Semih Lûtfi edition)
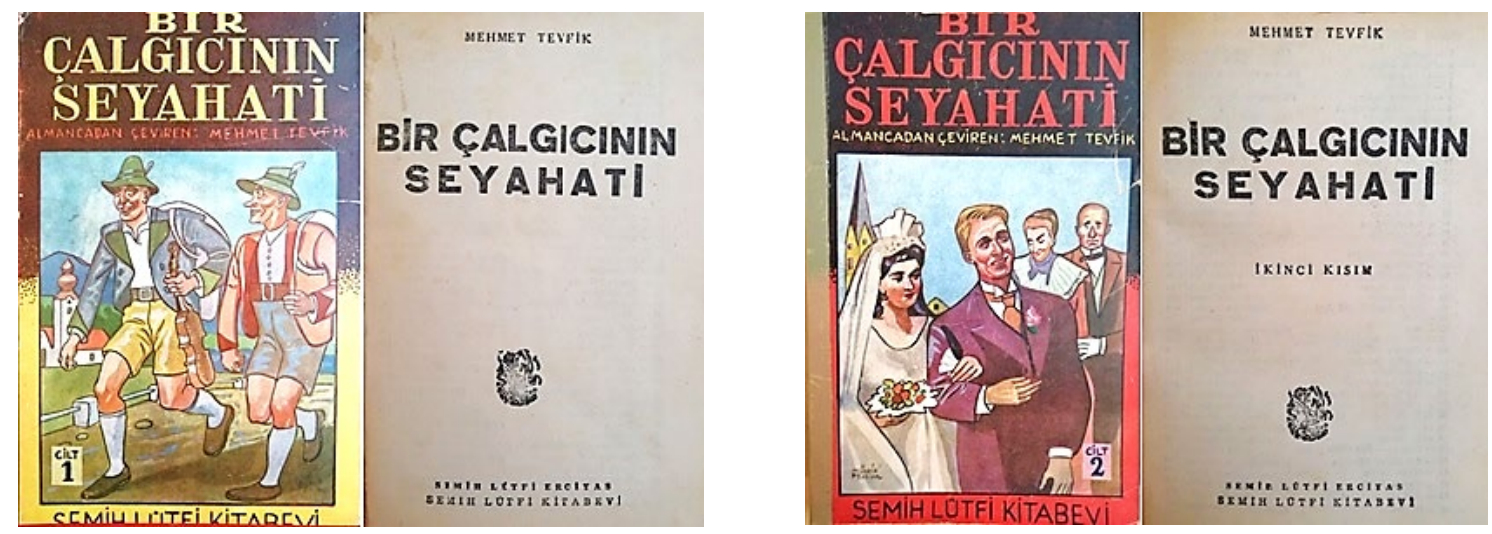

Figure 3. Front and inner covers of 1937 (Yeni Kitapçı) (top), 1945 (Ahmet Halit Yaşaroğlu) (bottom left), and 1953 (Ahmet Halit Yaşaroğlu) (bottom right) editions of Bir Çalgıcının Seyahati

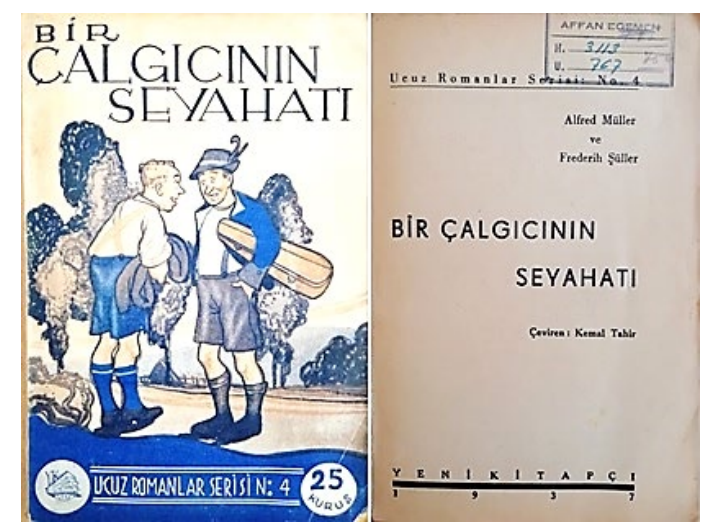



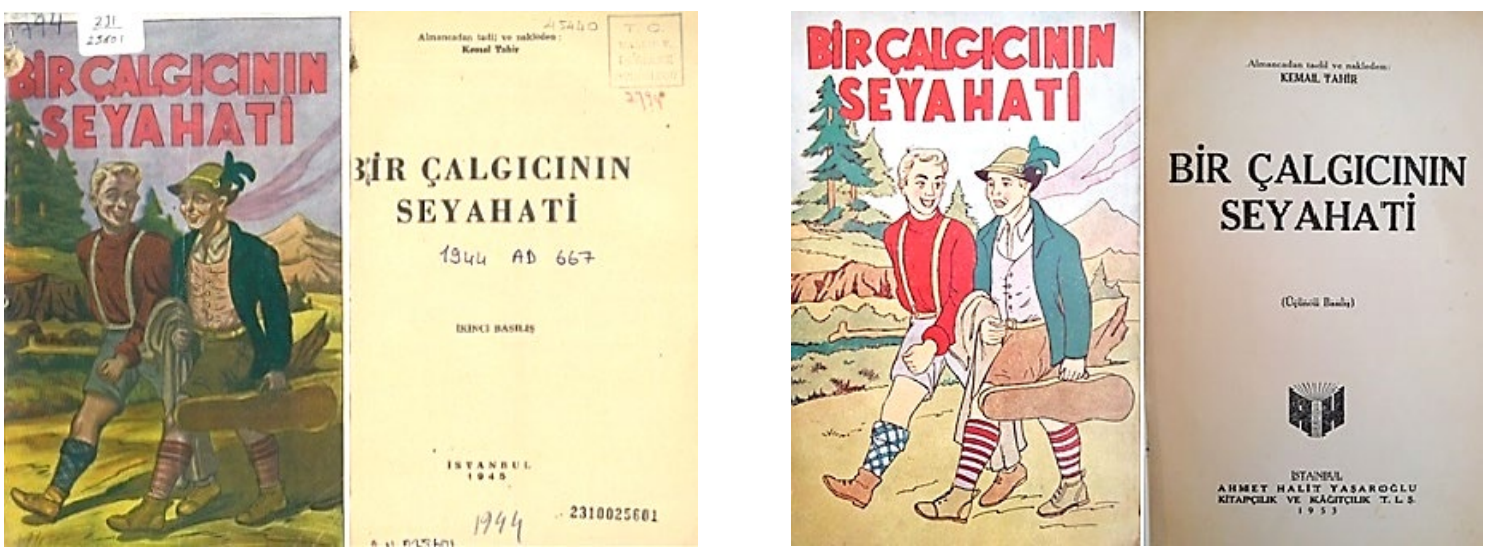

Figure 4. Front dust jacket and inner cover of Bir Çalgıcının Seyahati (1972; Atlas edition)

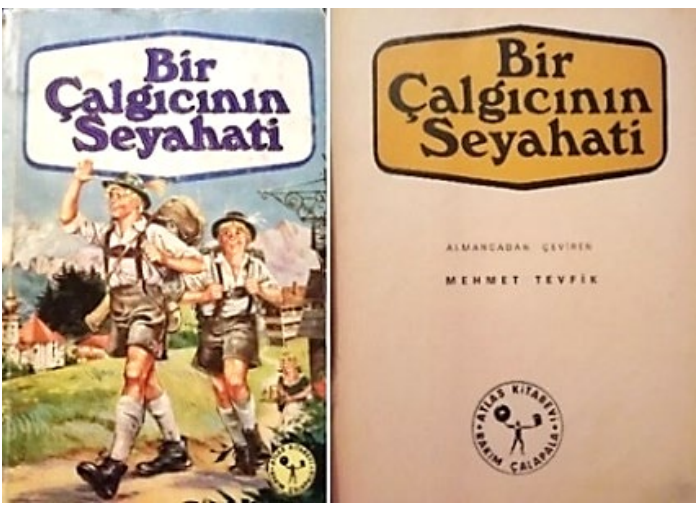

Figure 5. Excerpt from pages 3-4 of Bir Çalgıcının Seyahati (1926)

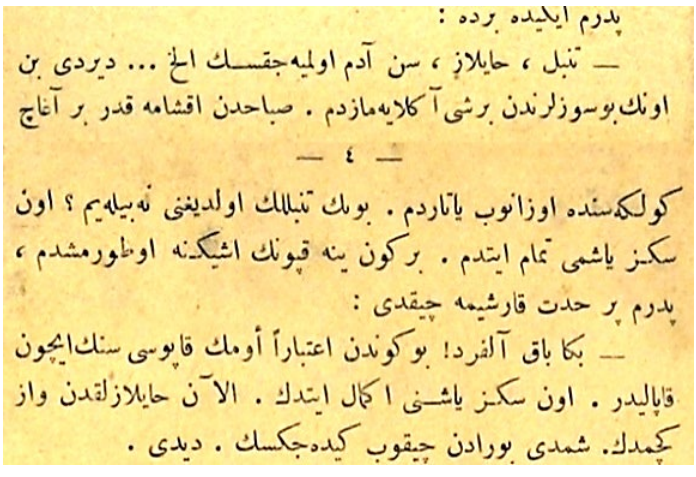

Pederim ikide birde:

- Tenbel, haylaz, sen adam olmayacaksin ilh... derdi ben onun bu sözlerinden bir şey anlayamazdım. Sabahdan akşama kadar bir ağaç gölgesinde uzanıp yatardım. Bunun tembellik olduğunu ne bileyim? On sekiz yaşımın tamam etdim. Bir gün yine kapının eşiğine oturmuşdum, pederim pür hiddet karşıma çıkdı:

-Bana bak Alfred! $\mathrm{Bu}$ günden itibaren evimin kapısı senin için kapalıdır. On sekiz yaşını ikmal etdin. El'an haylazlıkdan vaz geçmedin. Şimdi buradan çıkıp gideceksin. Dedi. 
Figure 6. Excerpt from page 4 of Bir Çalgıcının Seyahati (1926)

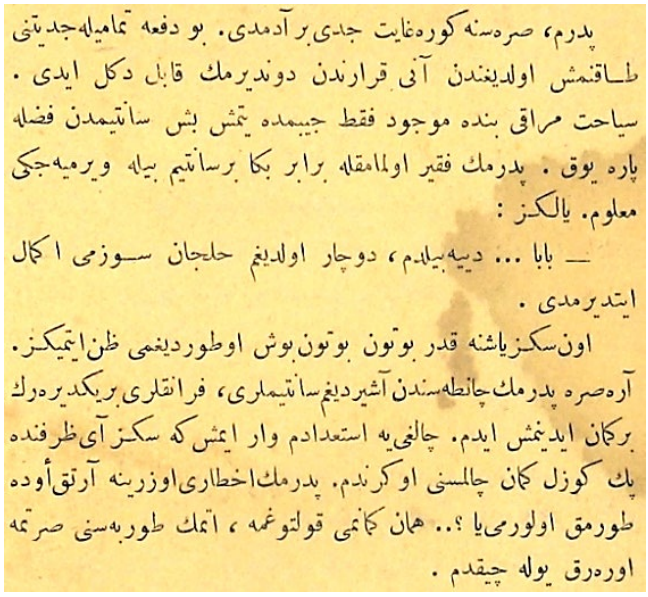

Pederim, sirasina göre gayet ciddi bir adamdı. $\mathrm{Bu}$ defa tamamıla ciddiyetini takınmış olduğundan ânı kararından döndürmek kabil değil idi. Seyahat merakı bende mevcut fakat cebimde yetmiş beş santimden fazla para yok. Pederimin fakir olmamakla beraber bana bir santim bile vermeyeceği mağlum. Yalnız:

—Baba... diyebildim, düçar olduğum helecân sözümü ikmâl ettirmedi.

On sekiz yaşına kadar bütün bütün boş oturduğumu zan itmeyiniz. Ara sıra pederimin çantasından aşırdığım santimleri, frankları birikdirerek bir keman idinmiş idim. Çalgıya istidadım var imiş ki sekiz ay zarfında pek güzel keman çalmasını öğrendim. Pederimin ihtarı üzerine artık evde durmak olur mu ya?.. Heman kemanımı koltuğuma, ekmek torbasını sırtıma urarak yola çıkdım.

Figure 7. Excerpt from pages 5, 6, 7 of Bir Çalgıcının Seyahati (1926)

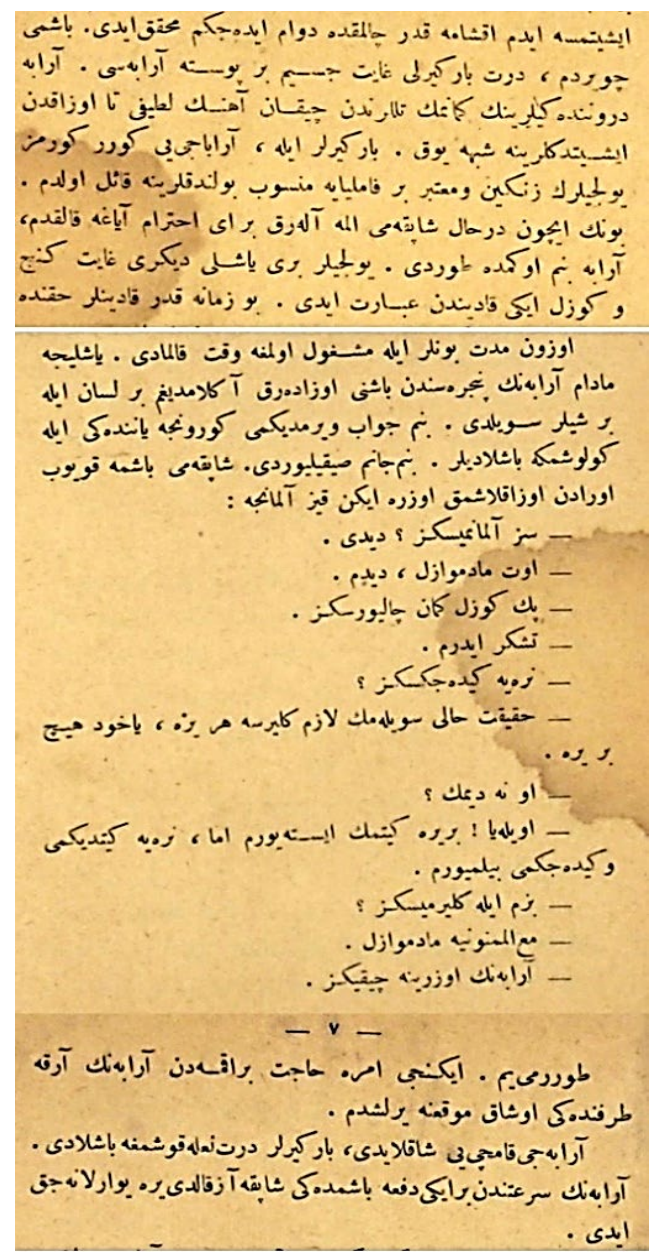

Başımı çevirdim, dört bargirli gayet cesim bir posta arabası. Araba derunundakilerinin kemanımın tellerinden çıkan aheng-i latifi ta uzakdan işitdiklerine şüphe yok. Bargirler ile, arabacıyı görür görmez yolcuların zengin ve muteber bir familyaya mensub bulunduklarına kail oldum. Bunun için derhal şapkamı elime alarak berây-1 ihtiram ayağa kalkdım, araba benim önümde durdu. Yolcular biri yaşlı diğeri gayet genç ve güzel iki kadından ibaret idi. [...]

Uzun müddet bunlarla meşgul olmağa vakit kalmadı. Yaşlıca madam arabanın penceresinden başını uzatarak anlamadığım bir lisan ile bir şeyler söyledi. Benim cevab virmediğimi görünce yanındaki ile gülüşmeğe başladılar. Benim canım sıkılıyordu. Şapkamı başıma koyub oradan uzaklaşmak üzere iken kız Almanca:

- Siz Almanmisiniz? Dedi.

-Evet madmuazel, dedim.

-Pek güzel keman çaliyorsunuz.

- Teşekkür iderim.

-Nereye gideceksiniz?

- Hakikat hali söylemek lazım gelirse her yere, yahud hiç bir yere.

-O ne dimek?

—Öyle ya! Bir yere gitmek istiyorum ama nereye gitdiğimi ve gideceğimi bilmiyorum.

-Bizim ile gelirmisiniz?

—Maalmemnûniye madmuazel. 
-Arabanın üzerine çıkınız.

Durur muyum. İkinci emre hacet birakmadan arabanın arka tarafındaki uşak mevkiine yerleştim. Arabacı kamçıyı şakla[t]dı, bargirler dört nala koşmağa başladı. Arabanın sür'atinden bir iki def'a başımdaki şapka az kaldı yere yuvarlanacak idi.

Figure 8. Excerpt from page 45 of Bir Çalgıcının Seyahati (1926)

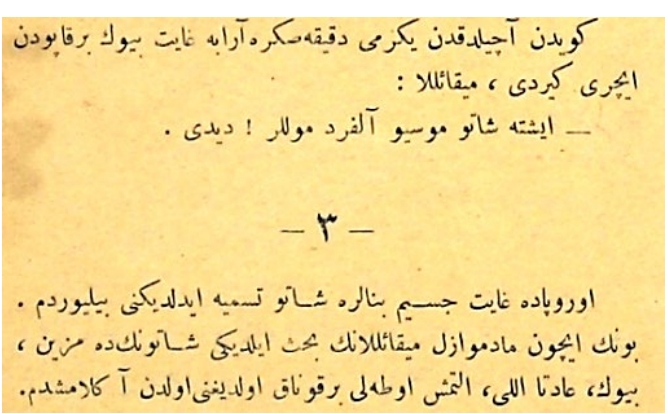

Köyden açıldıktan yirmi dakika sonra araba gayet büyük bir kapıdan içeri girdi, Mikaella:

- İşte şato mösyö Alfred Müller! dedi.

Avrupada gayet cesim binalar şato tesmiye idildiğini biliyordum. Bunun için madmuazel Mikaellanın bahs eylediği şatonun da müzeyyen, büyük, adeta elli, altmış odalı bir konak olduğunu evvelden anlamıştım.

Figure 9. Excerpt from pages 51-52 of Bir Çalgıcının Seyahati (1926)

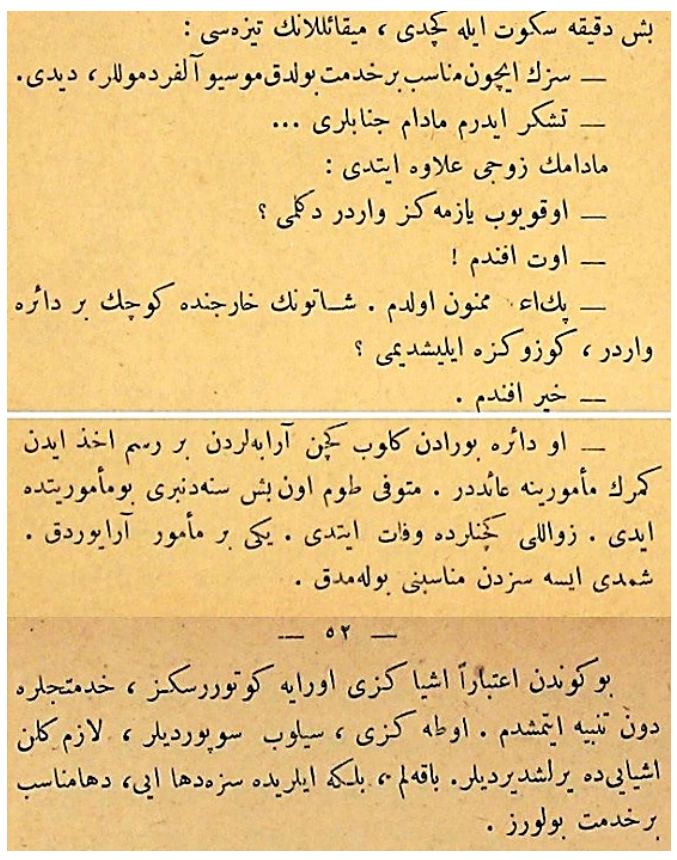

Mikaella'nın teyzesi:

—Sizin için münasib bir hizmet bulduk mösyö Alfred Müller, dedi:

- Teşekkür ederim madam cenabları...

Madamın zevci ilave etti:

-Okuyup yazmanız vardır değilmi?

-Evet efendim!

-Pekala memnun oldum. Şatonun haricinde küçük bir daire vardır, gözünüze ilişdi mi?

- Hayır efendim.

$[\ldots]$

-O daire buradan gelip geçen arabalardan bir resim ahzeden gümrük memuruna aitdir. Müteveffa Tom on beş seneden beri bu memuriyette idi. Zavallı geçenlerde vefat etti. Yeni bir memur aryyorduk. Simdi ise sizden münasibini bulamadık.

$\mathrm{Bu}$ günden itibaren eşyanızı oraya götürürsünüz, hizmetçilere dün tenbih etmişdim. Odanızı, silip süpürdüler, lazım gelen eşyayı da yerleştirdiler. Bakalım, belki ileride size daha iyi, daha münasib bir hizmet buluruz. 
Figure 10. Excerpt from pages 391-392 of Bir Çalgıcının Seyahati (1926)

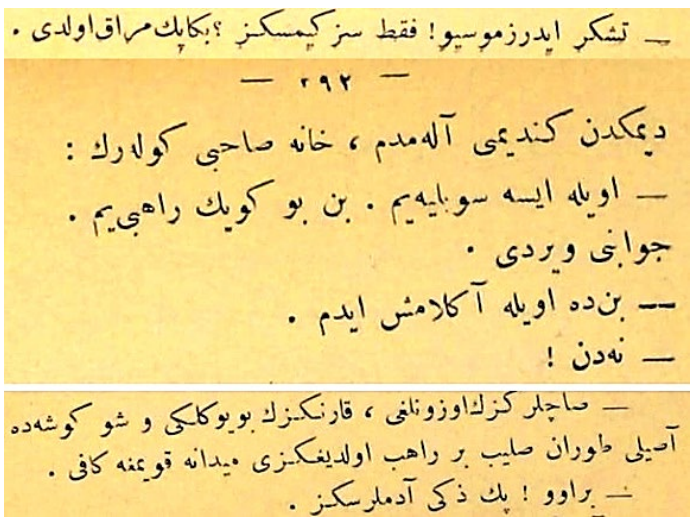

—-Teşekkür ederiz mösyö! Fakat siz kimsiniz? Bana pek merak oldu. Demekden kendimi alamadım, hane sahibi gülerek:

—Öyle ise söyleyeyim. Ben bu köyün rahibiyim.

Cevabinı verdi.

—Ben de öyle anlamış idim.

-Neden!

[...]

-Saçlarınızın uzunluğu, karnınızın büyüklüğü ve şu köşede asılı duran salib bir rahib olduğunuzu meydana koymağa kafi.

—Bravo! Pek zeki adamlarsınız.

Figure 11. Excerpt from page 400 of Bir Çalgıcının Seyahati (1926)

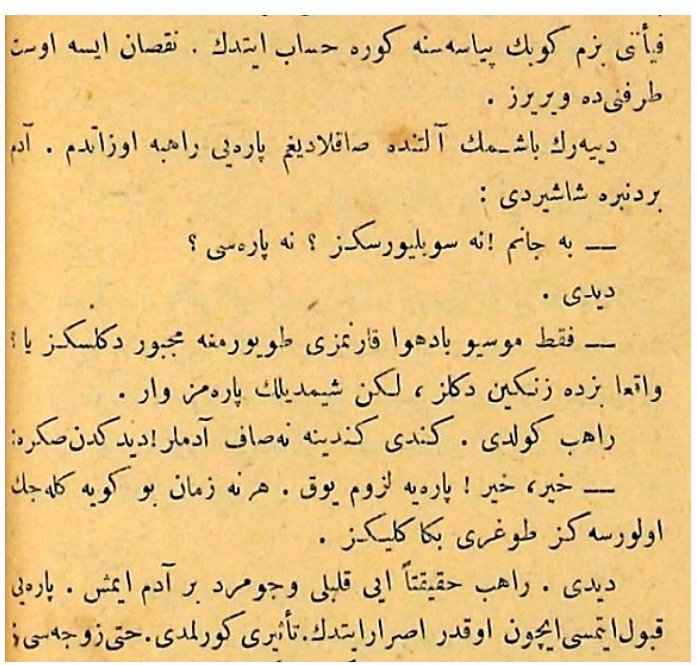

Noksan ise üst tarafinı da veririz.

Diyerek başımın altında sakladığım parayı rahibe uzatdım. Adam birdenbire şaşırdı:

—Be canım! Ne söylüyorsunuz? Ne parası?

Dedi.

—Fakat Mösyö badheva karnımızı doyurmaya mecbur değilsiniz ya? Vakıa biz de zengin degiliz, lakin şimdilik paramız var.

Rahip güldü. Kendi kendine ne saf adamlar! dedikten sonra:

-Hayır, hayır! Paraya lüzum yok. Her ne zaman bu köye gelecek olursanız doğru bana geliniz.

Dedi. Rahip hakikaten iyi kalbli ve cömerd bir adam imiş. Parayı kabul etmesi için o kadar 1srar etdik. Tesiri görülmedi.

\section{Figure 12. Excerpt from page 150 of Bir Çalgıcının Seyahati (1926)}

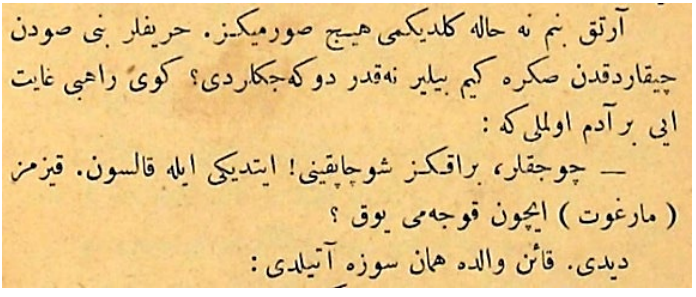

Artık benim ne hale geldiğimi hiç sormayınız. Herifler beni sudan çıkardıkdan sonra kim bilir ne kadar döğeceklerdi? Köy rahibi gayet iyi bir adam olmalı ki:

—Çocuklar, bırakınız şu çapkını! Etdiği ile kalsın. Kızımız (Margot) için koca mı yok? dedi.

Figure 13. Excerpt from page 3 of Bir Çalgıcının Seyahati (1926)

اوكرتمك ايهون نى مكتبه كوندرمك بله لزوب كورمهمشدى . فقط

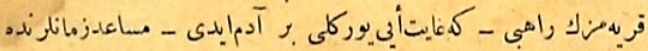

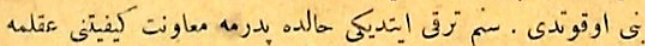

Fakat karyemizin rahibi - ki gayet iyi yürekli bir adam idi - müsaid zamanlarında beni okutdu. 
Figure 14. Excerpt from page 11 of Bir Çalgıcının Seyahati (1926)

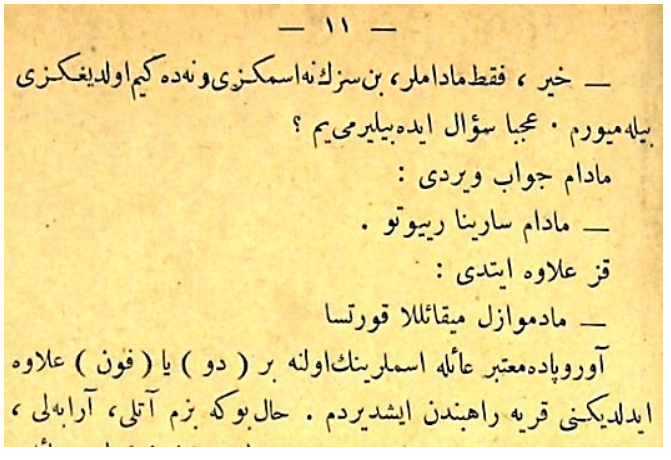

- Hayır, fakat madamlar, ben sizin ne isminizi ve ne de kim olduğunuzu bilemiyorum. Acaba sual edebilir miyim?

Madam cevab verdi:

-Madam Sarina Riyoto.

Kız ilave etdi:

- Madmuazel Mikaella Kortsa.

Avrupada muteber aile isimlerinin evveline bir (dö) veya (fon) ilave edildiğini karye rahibinden işidirdim.

Figure 15. Excerpt from pages 285-286 of Bir Çalgııının Seyahati (1926)

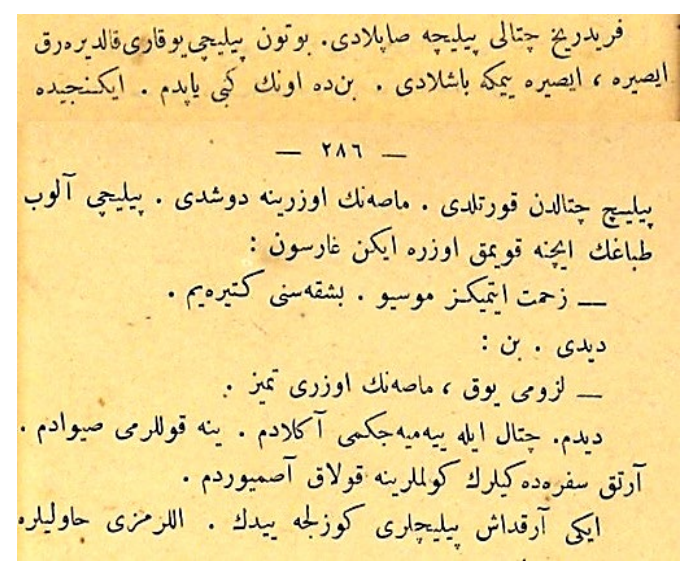

Fredrih çatalı pilice sapladı. Bütün pilici yukarı kaldırarak 1sıra, 1sıra yemeğe başladı. Bende onun gibi yapdım. İkincide piliç çataldan kurtuldu. Masanın üzerine düşdü. Pilici alıb tabağın içine koymak üzere iken garson:

-Zahmet etmeyiniz mösyö. Başkasını getireyim. Dedi. Ben:

—Lüzumu yok, masanın üzeri temiz.

Dedim. Çatal ile yiyemeyeceğimi anladım. Yine kollarımı sıvadım.

Artık sofradakilerin gülmelerine kulak asmıyordum. İki arkadaş piliçleri güzelce yedik.

Figure 16. Excerpt from pages 445-446 of Bir Çalgıcının Seyahati (1926)

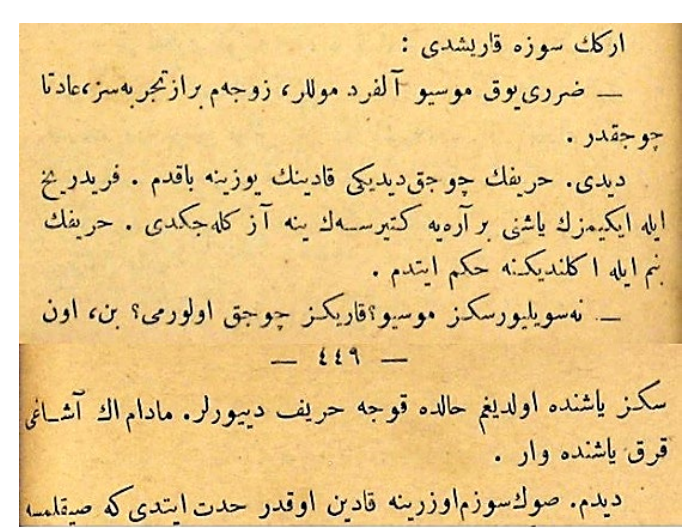

Erkek söze karışdı:

-Zararı yok mösyö Alfred Müller, zevcem biraz tecrübesiz, adeta çocukdur.

Dedi. Herifin çocuk dediği kadının yüzüne bakdım. Fredrih ile ikimizin yaşını bir araya getirsek yine az gelecekdi. Herifin benim ile eğlendiğine hükmettim. - Ne söylüyorsunuz mösyö? Karınız çocuk olur mu? Ben, on sekiz yaşında olduğum halde koca herif diyorlar. Madam en aşağı kırk yaşında var. Dedim. 


\section{References}

Alimen, Nilüfer. 2010. "The Ideological Aspect of the Pseudotranslations in Turkey: An Analysis of Kemal Tahir's Pseudotranslations of Mike Hammer Series." Master's thesis, Aston University.

. 2018. "Polisiye Edebiyatımızda Çeviriler ve Sözde Çeviriler." [Translations and pseudo translations in Turkish crime fiction.] Paper presented at the 5th Asoscongress International Symposium on Philology, Istanbul, October 25-27.

Alt, Nil. 2008. "A Gender-Based Study of Nihal Yeğinobalı's Pseudo-Translation Genç Kızlar.” Master's thesis, Boğaziçi University.

Baydere, Muhammed. 2019. "Çalıkuşu'nun Çeviri Serüveni." [The translational adventure of Çalıkuşu.] Unpublished manuscript, last modified July 3. Microsoft Word file.

Baydere, Muhammed, and Ayşe Banu Karadağ. 2019. "Çalıkuşu'nun Öz-Çeviri Serüveni Üzerine Betimleyici Bir Çalışma." [A descriptive study on the self-translation adventure of Çalıkuşu.] In "2nd International Rumeli Symposium [Language, Literature, Translation]," edited by Yakup Yılmaz and Fatih Başpınar. Special Issue, RumeliDE Journal of Language and Literature Studies, no. 5, 314-333. doi:10.29000/rumelide.606165.

Bengi-Öner, Işın. (1990) 1999. “Çeviribilim, Çeviri Kuramı ve Sözdeçeviriler.” [Translation Studies, translation theory, and pseudo translations.] Chap. 1 in Çeviri Bir Süreçtir... Ya Çeviribilim? [Translation is a process... What about Translation Studies?] Istanbul: Sel.

Berk Albachten, Özlem. 2013. 'Intralingual Translation as 'Modernization' of the Language: The Turkish Case.” Perspectives 21 (2): 257-271. doi:10.1080/0907676X.2012.702395.

2015. "The Turkish Language Reform and Intralingual Translation." In Tradition, Tension and Translation in Turkey, edited by Şehnaz Tahir Gürçağlar, Saliha Paker, and John Milton, 165-180. Amsterdam: John Benjamins.

. 2019. "Challenging the Boundaries of Translation and Filling the Gaps in Translation History: Two Cases of Intralingual Translation from the 19th-Century Ottoman Literary Scene." In Moving Boundaries in Translation Studies, edited by Helle V. Dam, Matilde Nisbeth Brøgger, and Karen Korning Zethsen, 168-180. London: Routledge. PDF e-book.

Boy, Hülya. 2018. "Eflatun Klz within the Context of Translation Studies: A Conceptual (Re)Framing." transLogos Translation Studies Journal 1 (1): 64-91. doi:10.29228/transLogos.1/1.9.

2019. "Bir Çalgıcının Seyahati'nin Türk Edebiyat ve Kültür Dizgesindeki Diliçi Çeviri Macerası." [The intralingual translation adventure of Bir Çalgıcının Seyahati in 
the Turkish literary and cultural system.] Paper presented at the 2nd International Rumeli [Language, Literature, Translation] Symposium, Kırklareli, April 12-13.

Çalapala, Rakım. 1972. "Bu Romanın Hikâyesi." [The story of this novel.] In Bir Çalgıcının Seyahati [The travels of a musician], translated by Mehmet Tevfik, 5-6. Istanbul: Atlas.

Demircioğlu, Cemal. 2005. "From Discourse to Practice: Rethinking 'Translation' (Terceme) and Related Practices of Text Production in the Late Ottoman Literary Tradition." PhD diss, Boğaziçi University.

2009. "Osmanlı Çeviri Tarihi Araştırmaları Açısından 'Terceme' ve 'Çeviri' Kavramlarını Yeniden Düşünmek." [Rethinking the concepts of 'terceme' and 'çeviri' from the perspective of studies on Ottoman translation history.] In "Festschrift in Honor of Cem Dilçin," edited by Zehra Toska. Special Issue, Journal of Turkish Studies 33 (1): 159-177. https://demircioglucemal.files.wordpress.com/2016/05/a3_2009_terceme-vec3a7eviri-kavramlarc4b1nc4b1-yeniden-dc3bcc59fc3bcnmek.pdf.

Eichendorff, Joseph Freiherrn von. 1826. Aus dem Leben eines Taugenichts und das Marmorbild [From the life of a good-for-nothing and the marble statue]. Berlin: Vereinsbuchhandlung.

Even-Zohar, Itamar. 1990. "The Position of Translated Literature within the Literary Polysystem." Poetics Today 11 (1): 45-51. doi:10.2307/1772668.

Gündüz, Doğan. 2017. "Bir Kitabın Serüveni: Bir Haylazın Hayatı'ndan Bir Çalgıcının Seyahati'ne... Bir Kitabın Macerası!" [A book's journey: From Aus dem Leben eines Taugenichts to Bir Çalgıcının Seyahati... The adventure of a book!] İyi Kitap, no. 90, 38-39. https://issuu.com/tudem/docs/iyikitap_90.

Kalem Bakkal, Asl1. 2019. "From the 'Real' Author to the 'Real' Reader: Manipulation in Translation." transLogos Translation Studies Journal 2 (1): 85-101. doi:10.29228/transLogos.2/1.5.

Karadağ, Ayşe Banu. 2019. “Türk Edebiyat ve Kültür Dizgesinin Konukseverliğinde Çeviri Roman Deneyimi." [Experience of translated novels with the hospitality of the Turkish literary and cultural system.] Doğu-Batı 22 (88): 9-25.

Lefevere, André. 1982. "Mother Courage's Cucumbers: Text, System and Refraction in a Theory of Literature.” Modern Language Studies 12 (4): 3-20. doi:10.2307/3194526.

. 1992. Translation, Rewriting, and the Manipulation of Literary Fame. London: Routledge.

. 2014. "Why Waste Our Time on Rewrites? The Trouble with Interpretation and the Role of Rewriting in an Alternative Paradigm." In The Manipulation of Literature: 
Studies in Literary Translation, edited by Theo Hermans, 215-243. New York: Routledge.

O’Sullivan, Carol. 2011. "Pseudotranslation." In Handbook of Translation Studies, edited by Yves Gambier and Luc van Doorslaer, 2:123-125. Amsterdam: John Benjamins.

Öncü, Mehmet Tahir. 2017. Türkçe Çeviriler Bibliyografyası: Dünya Edebiyatından Çeviriler [Bibliography of Turkish translations: Literatures of the world in Turkish translation]. Edited by Bahar Aliye Sertdemir and Gökhan Abac1. Istanbul: Hiperyayın.

Öztürk Baydere, Hilal. 2019. "Türk Edebiyatını Diliçi Çevirilerden Okumak: Osmanlıcada ve Günümüz Türkçesinde Refik Halid'in Guguklu Saat'i.” [Reading Turkish literature through intralingual translations: Refik Halid's Guguklu Saat in Ottoman and modern Turkish.] In Çeviri Üzerine Gözlemler [Observations on translation], edited by Seda Taş, 223-241. Istanbul: Hiperyayın.

Öztürk Kasar, Sündüz. 2009. "Les Pseudo-Traductions de Nihal Yeğinobalı: Auctorialité Féminine et Émancipation." [The pseudo translations of Nihal Yeğinoball: Female authorship and emancipation.] In Femmes Écrivains à la Croisée des Langues 17002000, edited by Agnese Fidecaro, Henriette Partzsch, Suzan van Dijk, and Valérie Cossy, 187-197. Geneva: Métis Presses.

Paker, Saliha. 2014. “Terceme, Te'lîf ve Özgünlük Meselesi.” [The issue of terceme, te'lif, and originality.] In Metnin Hâlleri: Osmanlı'da Telif, Tercüme ve Şerh [The states of text: Original, translation and commentary in the Ottoman tradition], edited by Hatice Aynur, Müjgân Çakır, Hanife Koncu, Selim S. Kuru, and Ali Emre Özyıldırım, 36-71. Istanbul: Klasik.

Rambelli, Paolo. 2009. "Pseudotranslation." In Routledge Encyclopedia of Translation Studies, edited by Mona Baker and Gabriela Saldanha, 208-211. London: Routledge.

Safa, Peyami. (1951) 2018. Yalnızız [We are lonely]. Istanbul: Ötüken.

Serhan, Fatma İrfan. 1979. Kemal Tahir'den Fatma İrfan'a Mektuplar [Letters from Kemal Tahir to Fatma İrfan]. Istanbul: Sander.

Şahin, Yelda. 2005. "Eichendorffs Novelle Aus dem Leben eines Taugenichts und ihre Übersetzungen ins Türkische: Eine übersetzungs- und literatur-wissenschaftliche Untersuchung." [Eichendorff's novella Aus dem Leben eines Taugenichts and its Turkish translations: A Translation and Literature Studies research.] PhD diss., Mersin University.

2012. "Die übersetzungsstrategische Grundposition der Belles Infidèles bei der Übersetzung europäischer Literatur in der Tanzimat-Periode." [The positioning of belles infidèles in terms of translation strategies in the translation of European literature in the Tanzimat period.] Hacettepe University Journal of Faculty of Letters 29 (2): 137-156. https://dergipark.org.tr/tr/download/article-file/619395. 
Tahir, Kemal, trans. 1937. Bir Çalgıcının Seyahatı [The travels of a musician]. n.p.: Yeni Kitapç1.

—, trans. 1945. Bir Çalgıcının Seyahati [The travels of a musician]. Istanbul: Ahmet Halit Yaşaroğlu.

—, trans. 1953. Bir Çalgıcının Seyahati [The travels of a musician]. Istanbul: Ahmet Halit Yaşaroğlu.

Tahir Gürçağlar, Şehnaz. 2008. The Politics and Poetics of Translation in Turkey, 1923-1960. Amsterdam: Rodopi.

- 2010. "Scouting the Borders of Translation: Pseudotranslation, Concealed Translations and Authorship in Twentieth-Century Turkey." In "Contemporary Perspectives on Translation in Turkey," edited by Elif Daldeniz. Special Issue, Translation Studies 3 (2): 172-187. doi:10.1080/14781701003647384.

Tellioğlu, Banu. 2019. “Özgünün Kökeni ve Çeviride Telif Hakları Meselesi.” [The origin of the original and the issue of translation copyright.] In Çeviribilimde Araştırmalar [Research in Translation Studies], edited by Seda Taş, 123-148. Istanbul: Hiperyayın.

Tevfik, Mehmet, trans. 1907/1908. Bir Çalgıcının Seyahati [The travels of a musician]. 2 vols. Istanbul: Saadet Matbaas1.

—, trans. 1921. Bir Çalgıcının Seyahati [The travels of a musician]. Istanbul: İkbal Kütüphanesi.

—, trans. 1926. Bir Çalgıcının Seyahati [The travels of a musician]. Istanbul: İkbal Kütüphanesi.

—, trans. 1945. Bir Çalgıcının Seyahati [The travels of a musician]. 2 vols. n.p.: Semih Lûtfi.

—, trans. 1972. Bir Çalgıcının Seyahati [The travels of a musician]. Istanbul: Atlas.

Toury, Gideon. 1995. Descriptive Translation Studies — and Beyond. Amsterdam: John Benjamins.

Yeni Sabah. 1940. "Yeni Tefrikamız Bir Çalgıcının Seyahati." [Our new serial Bir Çalgıcının $\begin{array}{llllll}\text { Seyahati.] July } & \text { 7. Jccessed July }\end{array}$ http://gazeteler.ankara.edu.tr/dergiler/68/1701/25780.pdf. 